\title{
Disegno di rilievo fondativo di una ricerca multidisciplinare presso il Complesso degli Incurabili
}

\author{
Rosaria Parente
}

Abstract

La ricerca sul complesso monumentale degli Incurabili, nel centro antico di Napoli, è stata un'esperienza di grande interesse per l'opportunità concessa inerente alla connessione e l'interazione tra saperi disciplinari. II fine è stato di ottimizzare le funzioni ospedaliere, quelle museali e il contenitore storico stesso. II rilievo e la rappresentazione complessa sono stati la condizione imprescindibile per integrare i differenti ambiti disciplinari. II ri-disegno, storicizzato alla data, permette, al rappresentatore di risalire alla forma generatrice del progetto, ripercorrendo il processo diacronico dalla sua creazione alle modificazioni intervenute nel tempo. II Complesso appare unitario in una contemporaneità di ciò che non ha la stessa data. L'attività di conoscenza e rilievo ha ripercorso, nel divenire delle forme del monumento, le tracce fondative del progetto originario e dei susseguenti, ha permesso di svelare le matrici geometriche che conferiscono la forma del modello fisico in relazione ai protocolli consolidati del rilievo. Dal progetto di discretizzazione e di misura della fisicità costruita inserita nel contesto ambientale, in relazione anche alle attività antropiche, l'attività condotta si è posta l'obiettivo di re-istituire un patrimonio di dati per rendere trasparente, attraverso il BIMH, l'evoluzione del complesso monumentale utile alla salvaguardia, alla tutela, e alla manutenzione del preesistente per orientare il progetto resiliente della fabbrica.

Parole chiave

tecnologie, rilievo, Incurabili, laser 3D, BIMH.
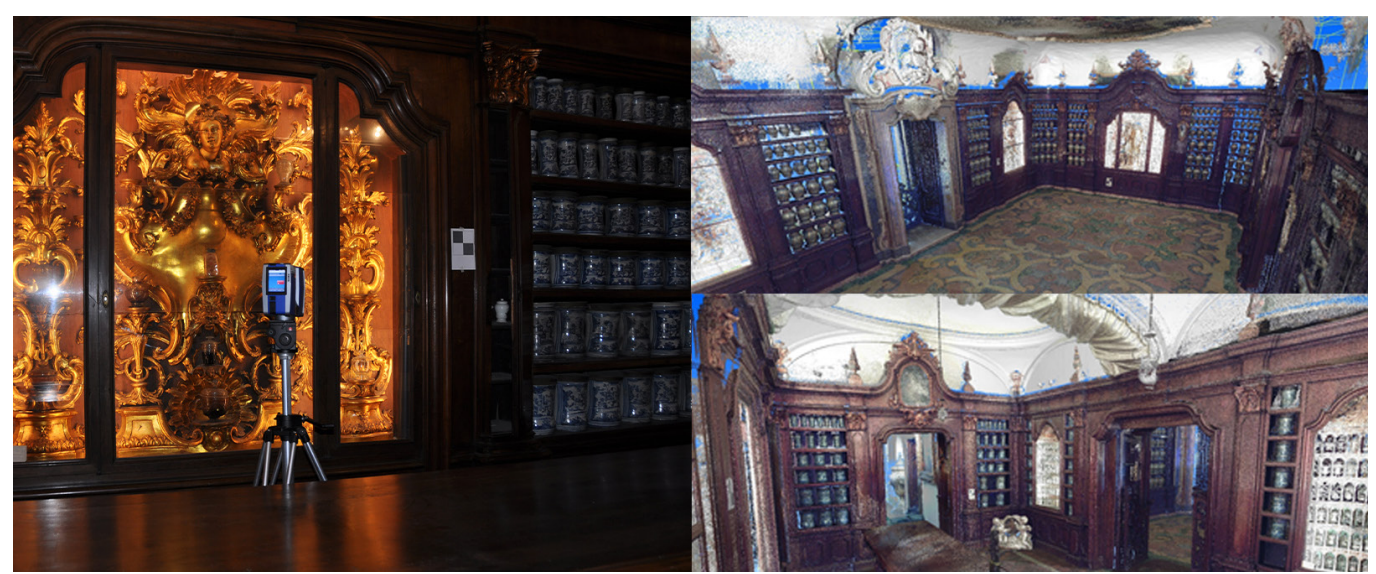


\section{Introduzione}

L'attività di rilievo e di conoscenza, che ho condotto su incarico del Consorzio Universitario Benecon, presso il complesso ospedaliero cinquecentesco Santa Maria degli Incurabili, imponente edificio la cui unicità architettonica, funzionale e storica lo ha reso uno dei luoghi significativi del Sito Patrimonio Mondiale UNESCO del Centro antico di Napoli, rientra in un articolato e innovativo programma strategico, fondato sulla partecipazione di competenze archeologiche, giuridiche, geologiche, geognostiche, di pianificazione territoriale, sismiche, strutturali, tecnologiche, di storia dell'architettura, restauro monumentale, e storico/artistiche $[\mathrm{I}]$.

Gli interventi di recupero e restauro si sono resi necessari, oltre che per una cattiva tenuta e manutenzione della struttura, soprattutto a seguito di diversi crolli che hanno interessato la volta a sostegno del pavimento della chiesa di Santa Maria del Popolo degli Incurabili all'interno del complesso monumentale. La connessione, creatasi tra le differenti competenze messe in campo, è stata di fondamentale importanza per la gestione della conoscenza di un bene architettonico così profondamente stratificato e contaminato. I saperi coinvolti hanno riguardato l'archeologia del sito di Caponapoli, l'architettura della fabbrica, l'evoluzione urbanistica fino allo studio del patrimonio storico e artistico, di cui la Farmacia settecentesca ne costituisce certamente la parte più importante e conosciuta. La Farmacia è un'opera dal punto di vista non solo architettonico ma anche storico artistico poiché in essa sono presenti importanti stalli lignei in cui è conservata una straordinaria collezione di albarelli e idrie decorati a chiaroscuro monocromatico con raffigurazioni bibliche e allegoriche, opera di Lorenzo Salandra. Essi rappresentano un unicum che va conservato nella sua interezza. Si tratta di piccoli vasi di forma cilindrica maiolicati e istoriati le cui raffigurazioni sono di sovente ripetute [Vitulli 2019].

Fig. I. Rilievo da piattaforma aerea Benecon, vista sulla città di Napoli e focus sulla Farmacia Storica di S. Maria del Popolo degli Incurabili.

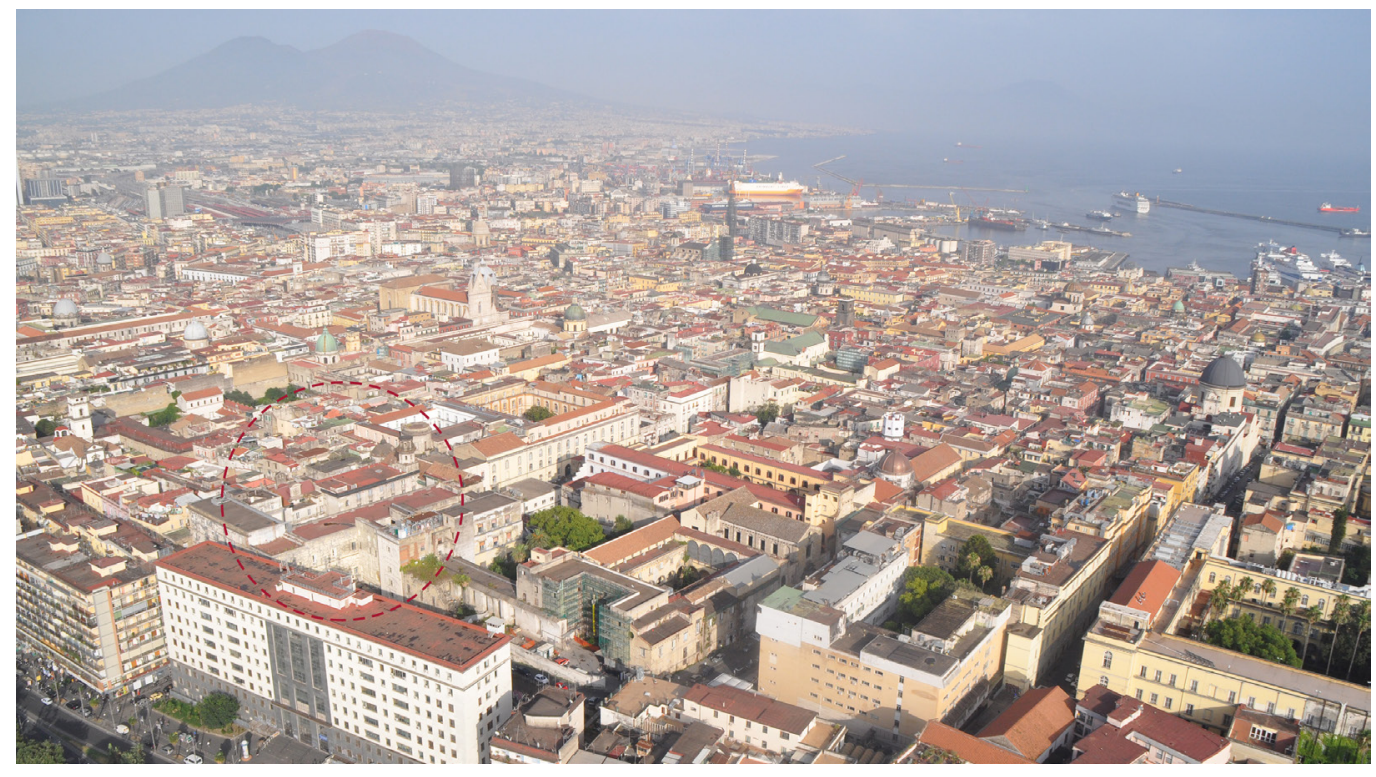

\section{Dal rilievo archeologico alla caratterizzazione spaziale e morfologica del manufatto architettonico}

II complesso monumentale è sito in un'area archeologica di grande interesse, Caponapoli, collina del governo nell'epoca greco-romana divenuta poi cittadella monastica, caratterizzata da salite e discese, tra piazze e chiostri antichi (fig. I). Sulle millenarie pietre di Caponapoli, tra la porta San Gennaro e quella di Costantinopoli, c'erano muniti bastioni a guardia della città ma sin dalla prima metà del Settecento sulle esigenze militari prevalse la cura dell'uo- 
Fig. 2. Focus sulla

Farmacia, rilievo aereo e rilievo fotografico in situ.

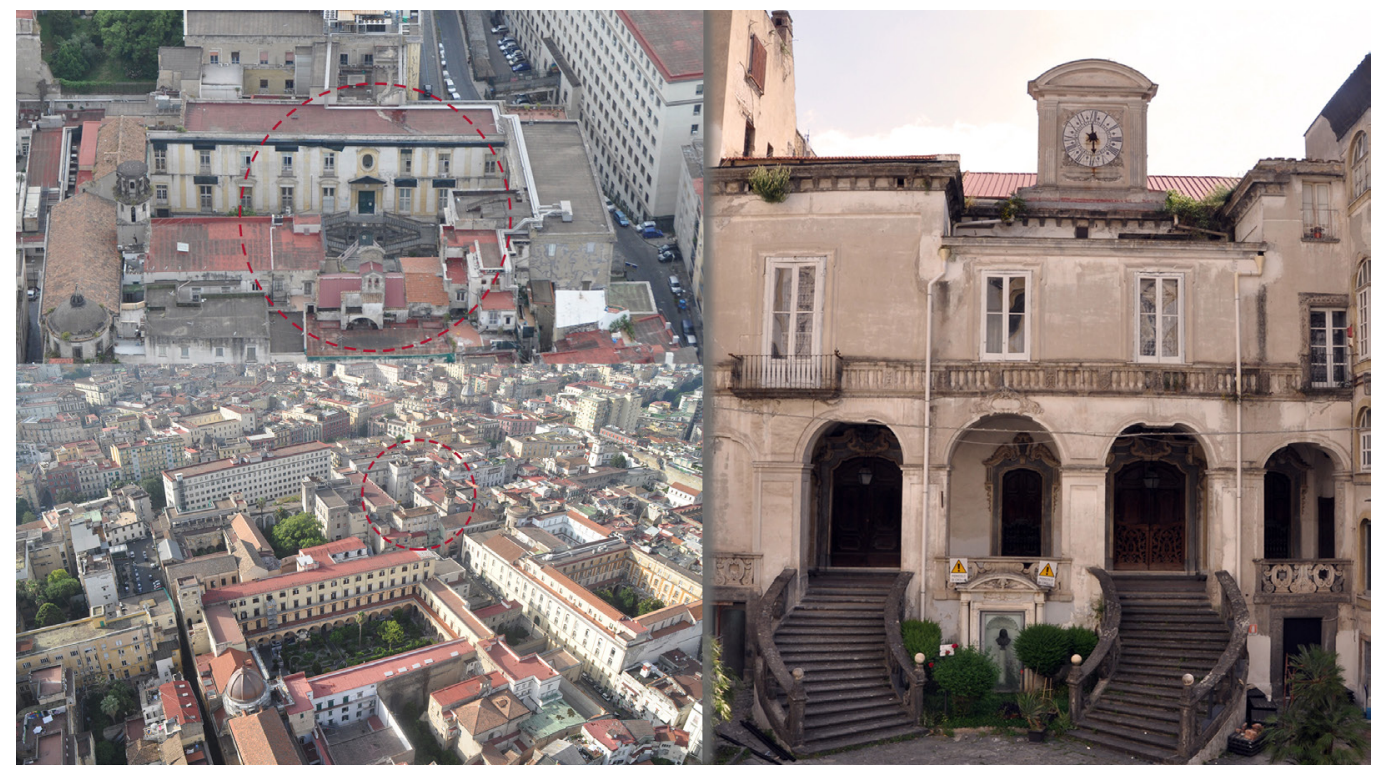

mo. II complesso è il frutto dell'unione di due distinti organismi: quello originario degli Incurabili, sommatoria di diversi interventi edilizi a partire dal I52I e nell'attuale configurazione dall'inizio dell'800, e il convento di Santa Maria delle Grazie a Caponapoli, la cui fondazione risale al |453, aggregato all'ospedale nel 1809.

Nel I52 I, Francesca Maria Longo, dopo una guarigione miracolosa, diede inizio ai lavorai per la costruzione dell'ospedale provvedendo ad acquistare alcune case in una zona salubre di Sant'Aniello, il sito più elevato dell'impianto greco di Neapolis ovvero l'area che prenderà il nome di Caponapoli e dove sorgerà la chiesa di Sant'Agnello maggiore nel Medioevo (fig. 2). II rilievo archeologico si è mostrato di fondamentale importanza per la definizione della stratificazione diacronica dell'area e dell'accumulazione dell'integrale dei volumi storici. Sono stati eseguiti sondaggi geo archeologici verticali a carotaggio continuo che hanno rilevato la presenza di diversi pozzi allineati lungo la direttrice degli stenopoi [2] di via Armanni e del vicolo della Consolazione. Ė stato rilevato anche un tratto settentrionale delle mura urbiche e una struttura in opera reticolata.

La contaminazione dei saperi ha trovato nel rilievo dal vero lo strumento principe per la rappresentazione del manufatto architettonico; tutti i saperi creano infatti studi propedeutici alla progettazione. I rilievi geometrici, elaborati con l'ausilio di tecnologie digitali, hanno consentito anche la definizione dell'attuale stato di degrado e di dissesto strutturale, a tutt'oggi in costante monitoraggio. Lo studio geologico del sito ha fornito con l'ausilio di ispezioni sotterranee, sondaggi e scavi per la conoscenza sub terra caratterizzata da terreni di origine vulcanica su base tufacea e di un antichissimo sistema di cavità e di pozzi. L'analisi geotecnica condotta anche attraverso indagini e verifiche strumentali ha ricostruito, nel breve periodo, i dissesti in fondazione e le cause naturali e antropiche che li hanno determinati.

II modello digitale si configura come il 'luogo' digitale nel quale archiviare analiticamente tutti i dati scientifici prodotti ex ante, in fieri ed ex post l'intervento di restauro, attestandosi quale modello digitale multidimensionale dell'Architettura, sempre implementabile e interrogabile a più livelli di approfondimento e secondo molteplici direzioni investigative [Pisacane 20 I7]. Le fasi di indagine e rappresentazione degli ambienti così come illustrati nella figura 3, sono state l'occasione per fare valutazioni sul ruolo del rilevatore che, indagando la realtà e rappresentandola, si impegna in un processo produttivo capace di avviare una filiera della conoscenza che, partendo dalla ricerca di tecnologie, strumenti, mezzi e superfici, materiali, colori crea le condizioni per servirsi di un linguaggio della rappresentazione come 'cassetta degli utensili' che usa per rintracciare, per rendere visibile e trasmettibile la cultura materiale, le fonti, il pensiero, gli stati d'animo, le emozioni. 
Fig. 3. Le fasi di indagine con laser scanner e la pianificazione per la rappresentazione degli ambienti rilevati.

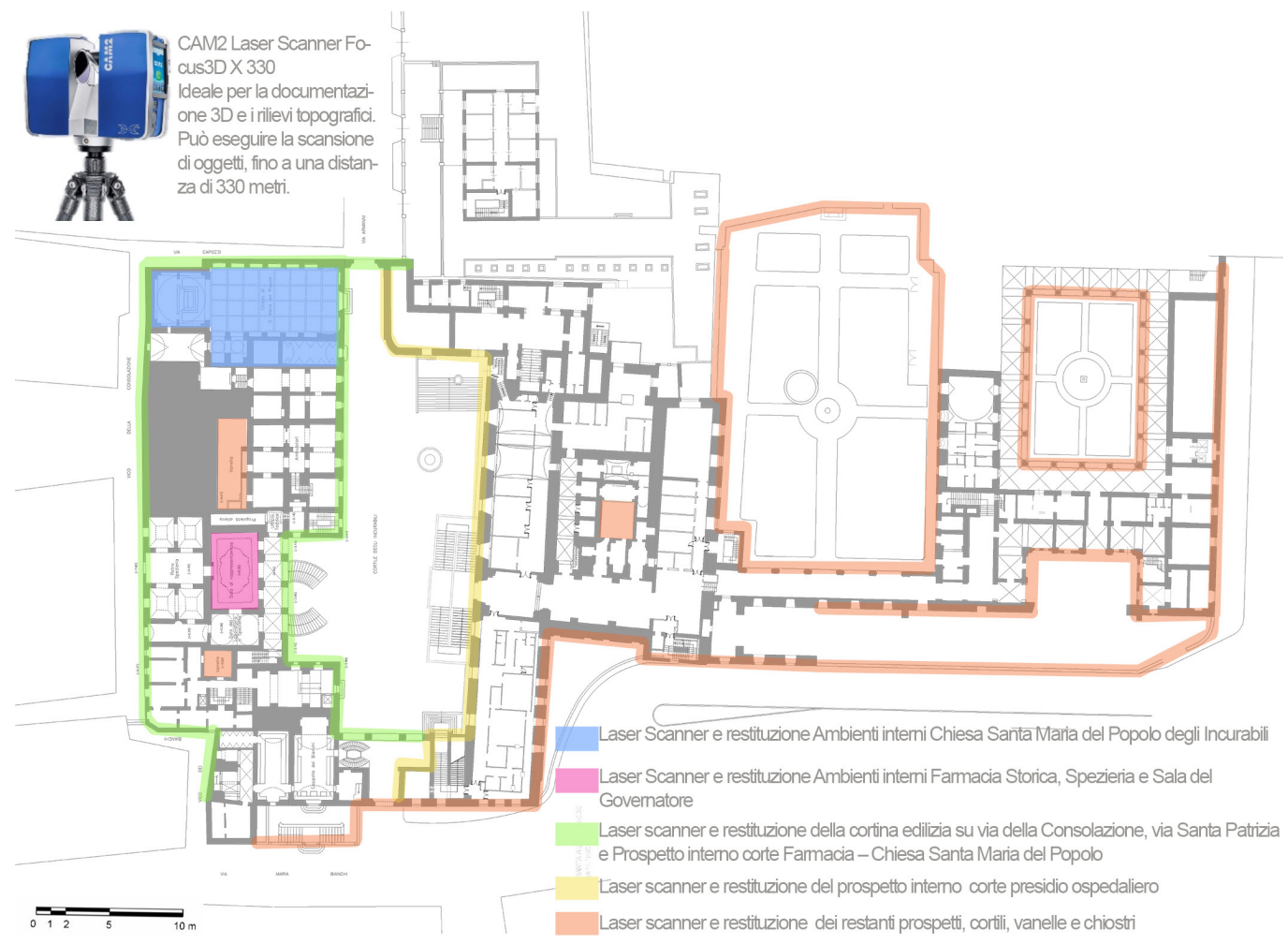

Misurare e patrimonializzare le infinite ragioni della natura, come ci raccomanda Leonardo, significa riconoscere il patrimonio genetico, l'identità dei luoghi fondativi di quel continuo processo di ripristino e di rigenerazione come modificazione contro ogni ipotesi di trasformazione: trasformare implica un'azione dettata solo da una necessità tecnologica condotta oltrepassando il limite imposto dalla conoscenza [Gambardella 2005].

La prima fase volta alla caratterizzazione geometrica e morfologica del manufatto architettonico è consistita nella materializzazione e definizione della rete topografica di inquadramento. Si tratta di una operazione fondamentale per la creazione di una rete a cui riferire le numerose scansioni ( 125 scansioni, 23 GB di raw data, più di 2 milioni di punti acquisiti) con laser scanner che hanno interessato gli ambienti interni della Farmacia storica, della Spezieria, della sala del Governatore e della chiesa di Santa Maria del Popolo nonché i prospetti delle cortine edilizie interne, i prospetti delle cortine edilizie esterne e il rilievo delle coperture dell'intero complesso (fig. I I ). Per ottenere un inquadramento planoaltimetrico preciso dell'area antistante la Farmacia, si è provveduto a eseguire un rilievo celerimetrico con stazione totale Trimble VX integrato da punti topografici acquisiti con ricevitore GNSS Trimble RI0, così da ottenere anche un posizionamento geografico preciso. II ricevitore GNSS è stato configurato in modalità NRTK (Network Real Time Kinematic) sfruttando così le correzioni differenziali della rete Italpos. Tale rete, a copertura nazionale, è composta da ricevitori GNSS funzionanti H24 -denominati Stazioni Permanenti- che forniscono in continuo dati per l'inquadramento topografico. I punti della suddetta rete possono definirsi vertici trigonometrici, essendo le loro coordinate e l'intera rete certificata dall'Istituto Geografico Militare Italiano (IGMI); pertanto, i punti ottenuti, grazie alle caratteristiche tecniche del ricevitore Trimble RIO in dotazione del Benecon, sono stati acquisiti con precisione sub centimetrica.

La rete topografica ha interessato, quindi, gli spazi aperti circostanti la Farmacia, la chiesa e tutto il complesso in modo da definire le quote relative e l'ubicazione spaziale dei sottoservizi interni ed esterni, possibile causa di degrado degli apparati architettonici e decorativi. Lo studio ha però previsto una prima fase conoscitiva dell'area interessata dall'intervento di restauro in ambiente GIS, è stato possibile confrontare il piano quotato realizzato con la sta- 
zione totale VX di proprietà del Consorzio Universitario Benecon e le quote da DTM della Regione Campania. Da questo confronto è stato possibile valutare eventuali cambiamenti di quota tra i punti rilevati nella campagna di acquisizione del mese di aprile 2019 e i punti dedotti dal DTM della Regione Campania datato 201 I.

La necessità di integrare informazioni relazionate a una univoca base informativa, se legata alla conoscenza di oggetti che si collocano in più ampi sistemi complessi, manifesta l'esigenza di produrre le informazioni grafiche attraverso un processo di rappresentazione e visualizzazione, tanto alla scala territoriale od urbana quanto a quella di dettaglio [Papa, D'Agostino 2020].

Dato l'elevato grado di interazioni tra le diverse discipline presenti nel progetto è necessario garantire un alto livello di integrazione tra modelli ed elaborati per una corretta conduzione dei livelli di progettazione. Secondo il principio della metodologia BIM del Being with the end in mind, i modelli informativi prodotti dovranno essere utilizzati in fase di realizzazione e gestione del Facility management [Salzano 2019] (fig. 12).

Fig. 4. II rilievo

tridimensionale degli ambienti interni e acquisizione dei punti topografici con ricevitor GNSS rimble RIO ne cortile antistante la Farmacia.

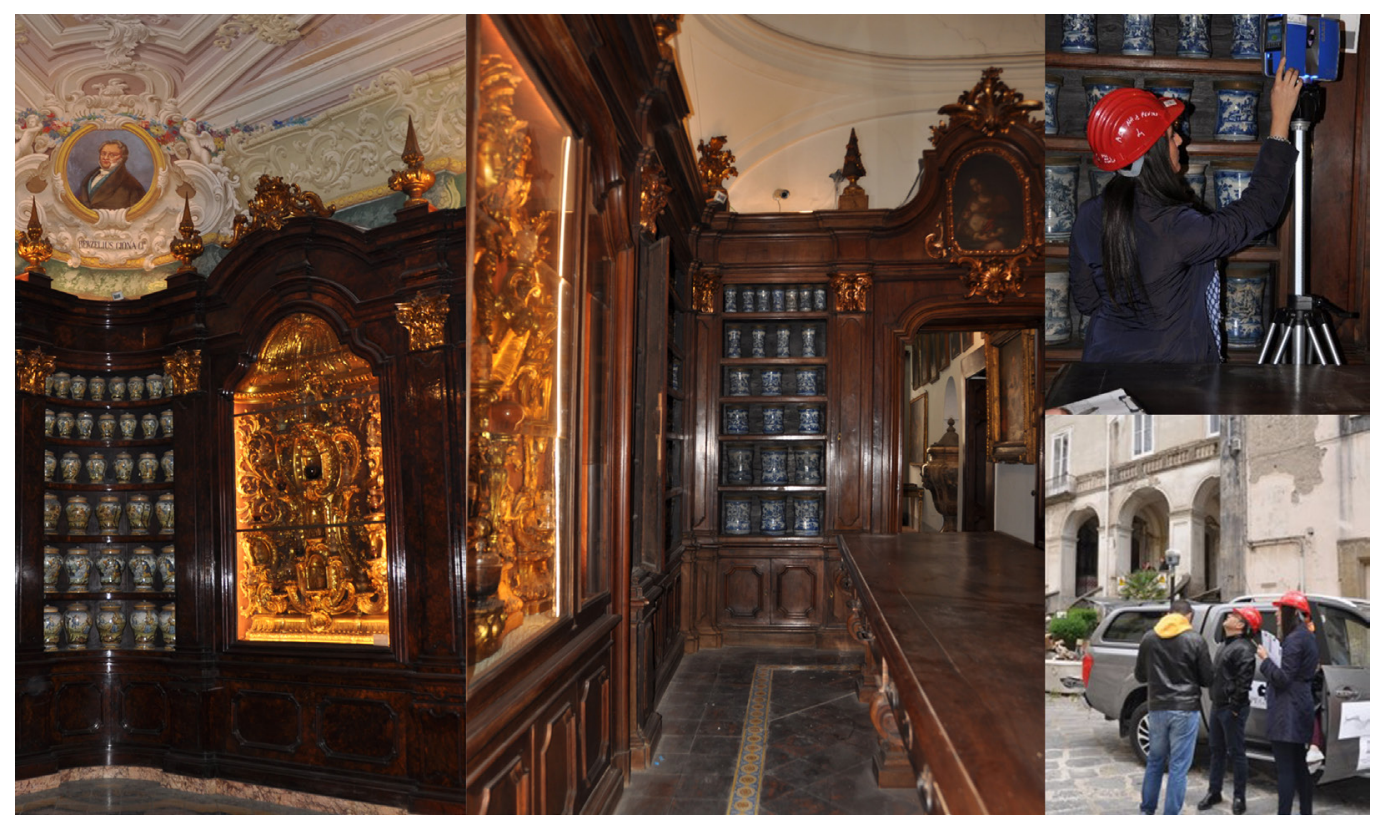

\section{II rilievo laser scanner}

L'attività di ricerca finalizzata all'intervento di restauro sull'opera, ha inteso fornire, attraverso il rilievo 3D, quell'apporto in termini di conoscenza storica, geometrica, costruttiva e stratigrafica, che appare sostanziale per le operazioni di conservazione, catalogazione e valorizzazione del bene architettonico.

Il complesso degli Incurabili si presenta in una conformazione frutto di diversi processi evolutivi che nel tempo lo hanno portato a essere un vero e proprio aggregato edilizio composto da diverse unità strutturali, edificate in epoche differenti e con un diverso grado di connessione tra di loro per cui ai fini della valutazione della sicurezza sismica, risultano indispensabili l'individuazione di unità originarie, il processo di evoluzione della struttura e l'individuazione della tecnica costruttiva locale. Per questo particolare tipo di strutture la fase di conoscenza attraverso l'utilizzo delle tecnologie laser scanner permette non solo di identificare gli elementi che compongono la struttura ma anche di definire le interazioni tra le diverse unità che compongono l'aggregato [Cosenza, Prota 2019].

La valutazione della sicurezza sismica ha riscontrato nel cattivo funzionamento dello smaltimento delle acque la probabile causa dei crolli verificatisi nell'area. 
Fig. 5. Pulizia e filtraggio della nuvola, mappatura con i dati immagine.

Fig. 6 Esempio di ortofoto, elaborata sulla vista interna della Farmacia, che non ha bisogno di correzioni di scala.
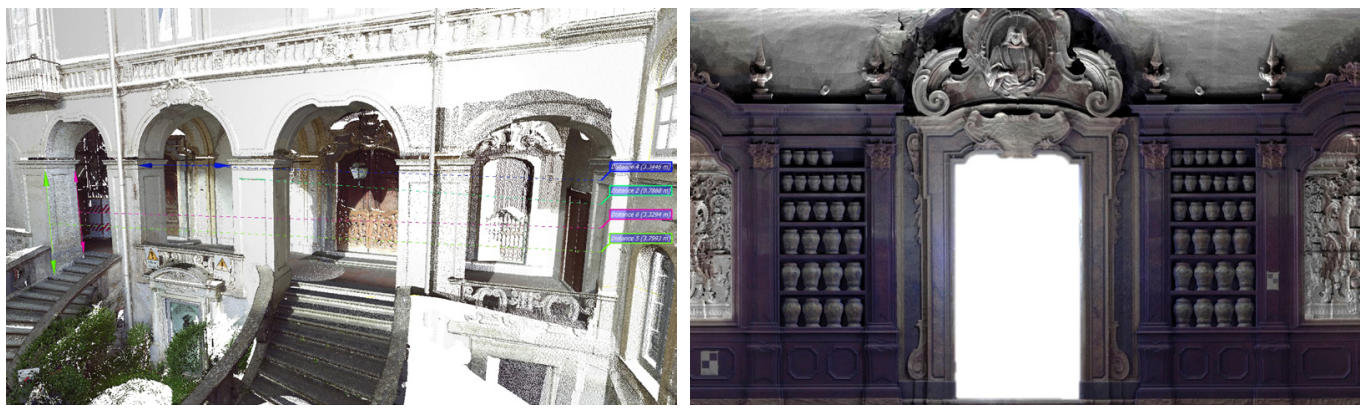

Le operazioni di rilievo sono state effettuate integrando l'uso di più strumentazioni terrestri e aviotrasportate. La tecnologia utilizzata per la restituzione della nuvola di punti è il FARO Focus3D X330, un laser scanner 3D a differenza di fase (fig. 4).

Come è noto, il rilievo automatico è caratterizzato da una sorta di incapacità dello strumento di misura di operare delle scelte 'intelligenti' [Cardaci, Innocenti 2020].

L'attività di scansione può richiedere infatti molto tempo e restituire un set di dati molto grandi e complessi per cui è di fondamentale importanza pianificare in anticipo i piani di scansione focalizzando e avendo ben chiaro l'obiettivo da raggiungere. II laser rileva tutti gli elementi che incontra nella scena della ripresa, per cui è necessario pulire e filtrare le nuvole dei punti. Ultimate queste fasi di pulizia e filtraggio, la nuvola, risultante dal mosaico delle I25 nuvole rilevate, è stata mappata con i dati immagine per consentire una identificazione più precisa delle textures e delle caratteristiche della struttura (fig. 5).

Se da un lato, il laser a scansione rileva tutto ciò che è intorno a lui e a lui è visibile, senza però realmente vedere ciò che misura e senza distinguere per importanza le parti dell'edificio, è pur vero che ciò permette di estrarre ortofoto misurabili che rappresentano una fonte preziosa dello stato dei luoghi alla data poiché nessun particolare può sfuggire a questo di tipo rilievo per cui, laddove ogni elemento potrebbe essere interpretato semplicemente come una sequenza di punti distanziati da parte della tecnologia, è lì che interviene il primato della mente owvero si può ribadire il primato fondativo di 'disegnare nella nostra mente'. In definitiva, uno strumento di acquisizione automatica non possiede la capacità umana di interpretare forme e geometrie ed è atto a restituire, quindi, proiezioni ortografiche e/o

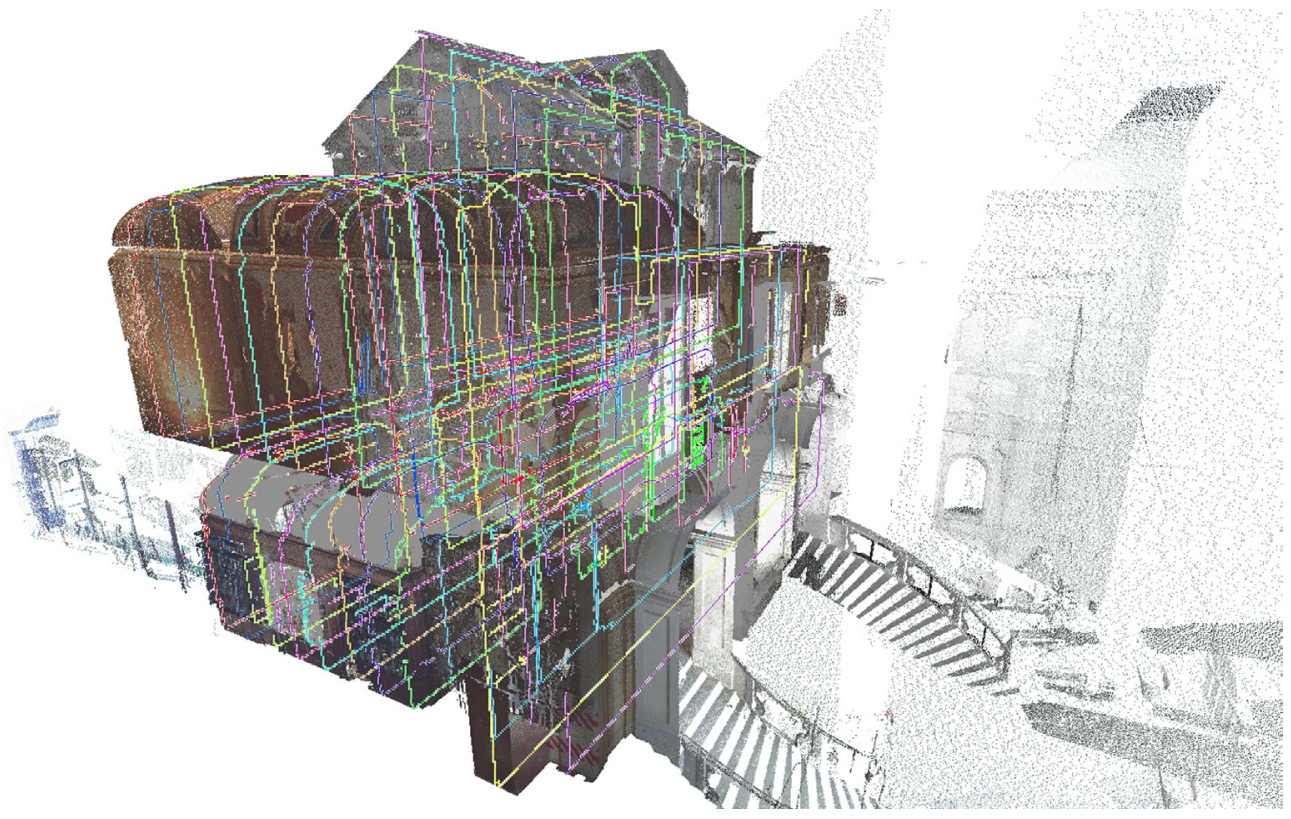

Fig. 7. I tanti possibili slicing che si possono elaborare per la caratterizzazione e il disegno del manufatto architettonico. 

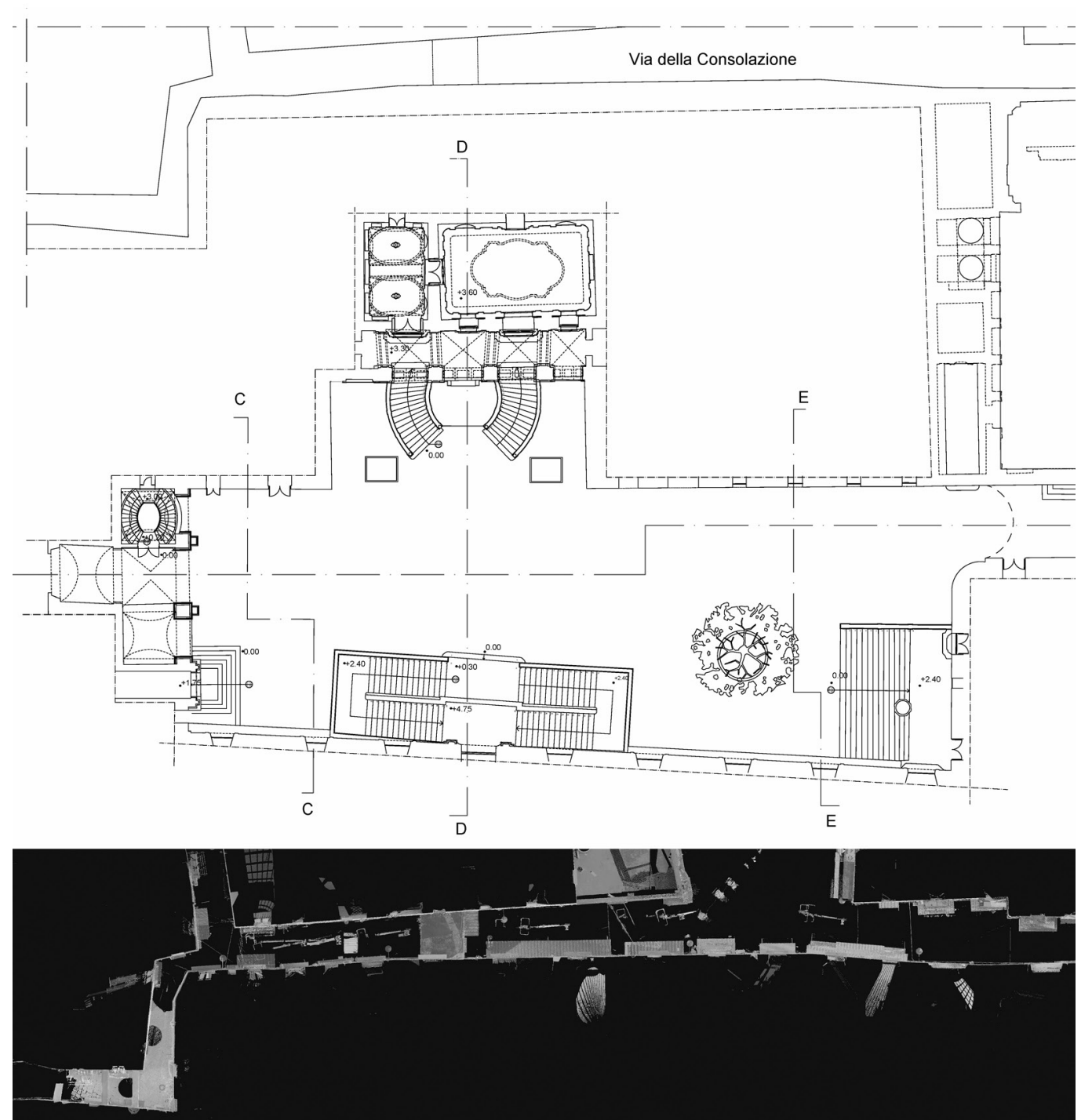

Fig. 8. Confronto tra l'elaborazione 2D dell corte interna della Farmacia e l'ortofoto della stessa.

Planimetria corte interna Farmacia +6.50 
cross-section, quali semplici sequenze di punti, non condizionate da una forse erronea e precedente interpretazione della spazialità del monumento (figg. 6, 7).

Ma la possibilità di sovrapporre in trasparenza i rilievi dell'esterno e dellinterno ha portato a considerare e verificare, nel caso di studio in oggetto, alcune interpretazioni funzionali dell'edificio, vale a dire è stato possibile estrapolare viste rettificate di insieme che hanno mostrato in tempo reale lo stato fessurativo delle murature, cedimenti e avvallamenti nei solai come nel caso emblematico della stanza sovrastante la sala della Farmacia, o dell'andamento topografico di vico della Consolazione, prospiciente il corpo di fabbrica maggiormente interessato dal crollo (figg. 8, 9).

È quasi certo che alcuni particolari esigui non sarebbero stati evidenziati da un rilievo di tipo tradizionale poiché, solo al momento della generazione nel software dedicato è stato possibile scegliere sia il piano di sezione ma anche il range di profondità e quindi visibilità dello stesso in modo da ottenere tanti slicing quanti ritenuti fondamentali per la caratterizzazione e il disegno delle geometrie più complesse.

A valle di ciò, in riferimento alla tematica della tecnologia qui trattata, risultano attuali le riflessioni di Ornella Zerlenga in merito allinnovazione tecnologica che potenzia i modi del fare e, per certi aspetti, introduce anche nuove forme del fare, ma la costruzione del progetto resta governata dalla sensibilità culturale ed etica di chi lo intuisce, lo sviluppa, lo realizza, almeno per ora, dove è ancora esistente fra uomo e computer una sostanziale distinzione, che segna la differenza fra i due: la dimensione organica, per il primo, e inorganica, per il secondo, e dunque, la possibilità per il primo di essere intelligente, libero di scegliere.

Fig. 9. Sezione di insieme sul corpo della Farmacia storica sul lato via Maria Longo.
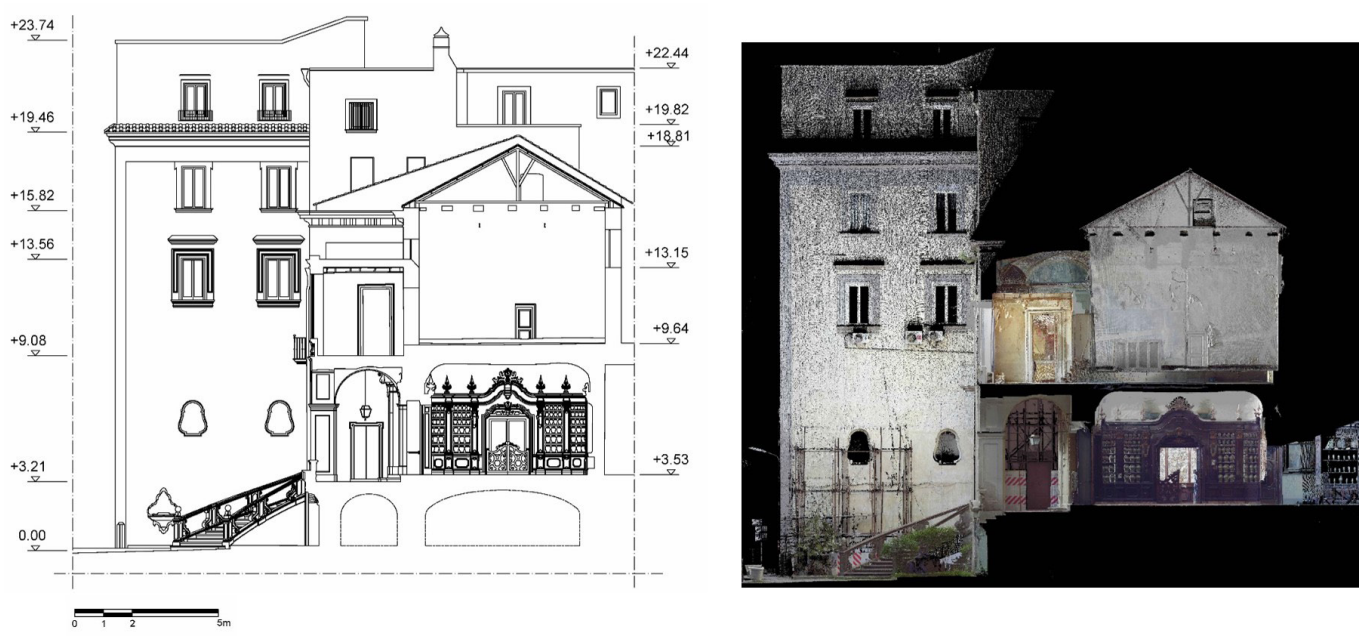

\section{Conclusioni}

La connessione e la contaminazione tra le più diverse discipline e i diversi saperi, nella ricerca oggetto delle presenti note, hanno permesso al Disegno di riaffermare il proprio ruolo di 'sintesi' tra le scienze umane e sociali e le scienze dell'ingegneria e dell'informatica. Non si tratta solo di rilevare, ma di 'interpretare' e trarre inferenze per poter poi intervenire nell'ambito di un pensiero plurale, fondato sulla multidimensionalità dei saperi [Fatta 2020]. La restituzione di un quadro conoscitivo, così approfondito ed esaustivo del sito e della fabbrica degli Incurabili, ha consentito agli stessi esperti la definizione degli indirizzi metodologici per la riqualificazione a scala urbana, il risanamento statico conservativo e il restauro architettonico e artistico. II ripristino dell'ospedale degli Incurabili verrà attuato attraverso il riuso dello stesso, in parte come struttura museale e in parte come struttura socio-sanitaria a valenza territoriale. I tesori del passato vanno digeriti e assimilati per essere ricreati owero per alimentare la missione che ogni generazione deve affrontare per dare alla eredità una prospettiva inedita. 
Fig. 10. A destra il prospetto dell'ingresso principale su via Maria Longo; a sinistra il prospetto nord su via Capozzi.
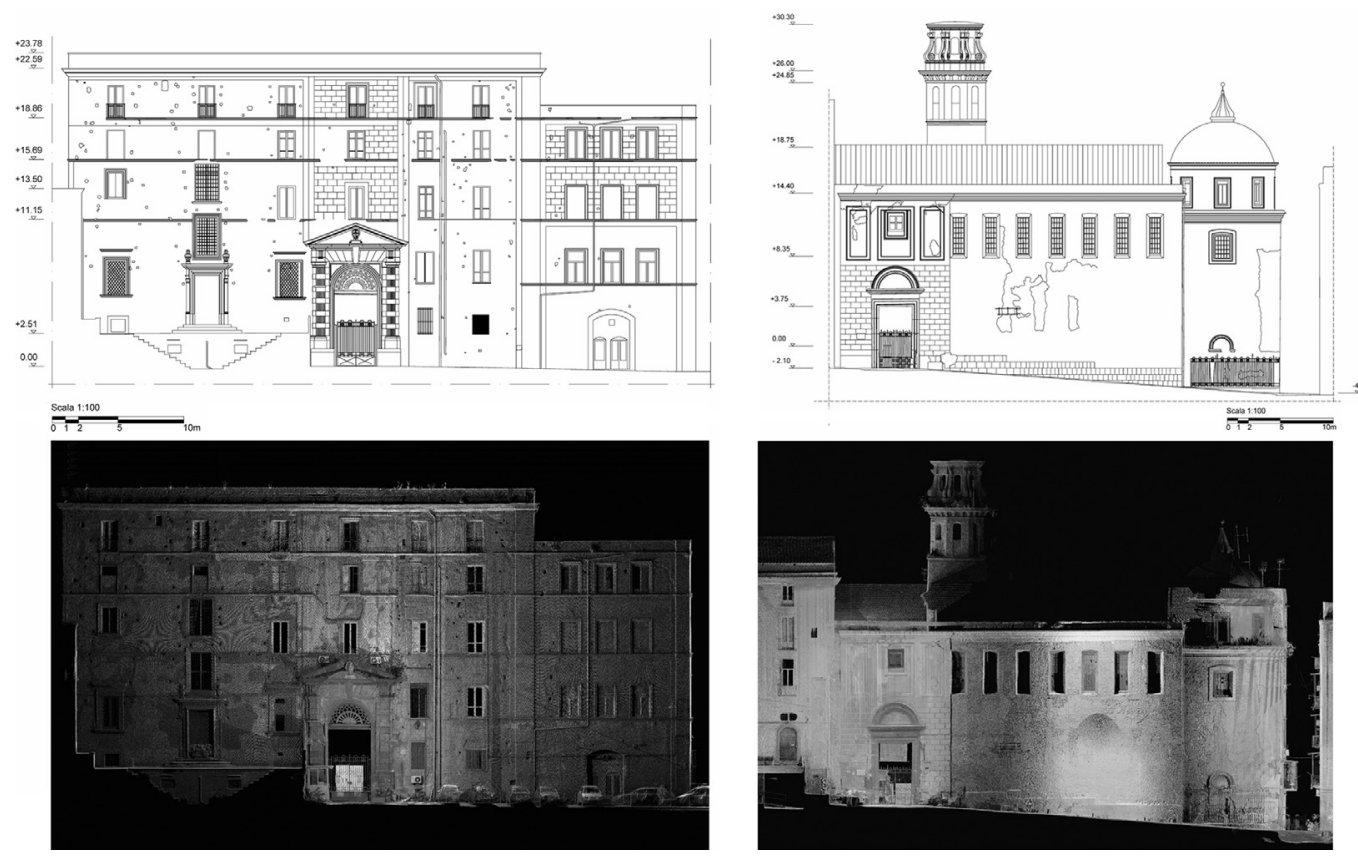

L'eredità reclama l'interpretazione ma anche la capacità di ri-creare, di utilizzare i talenti ricevuti mettendoli a frutto, di guardare con nuovi occhi il passato, non solo per ascoltarlo, ma anche per decidere liberamente in che direzione proseguire il cammino [Portoghesi 2018].

In quest'ottica, il settore disciplinare del Disegno si è dimostrato, con la sua ampia gamma di tecnologie e la sua capacità di risalire al segno minimo e al rapporto tra le parti, come il medium più efficace di rappresentazione dell'eredità lasciataci dal I500 dalla fondatrice dell'Ospedale degli Incurabili, Maria Longo.

Il caso studio è paradigmatico per i moltissimi ospedali monumentali presenti in tutta Italia, che hanno funzione rilevante per il territorio e potrebbero trovare nei progetti del Recovery Fund il modo di essere restaurati e salvaguardati.
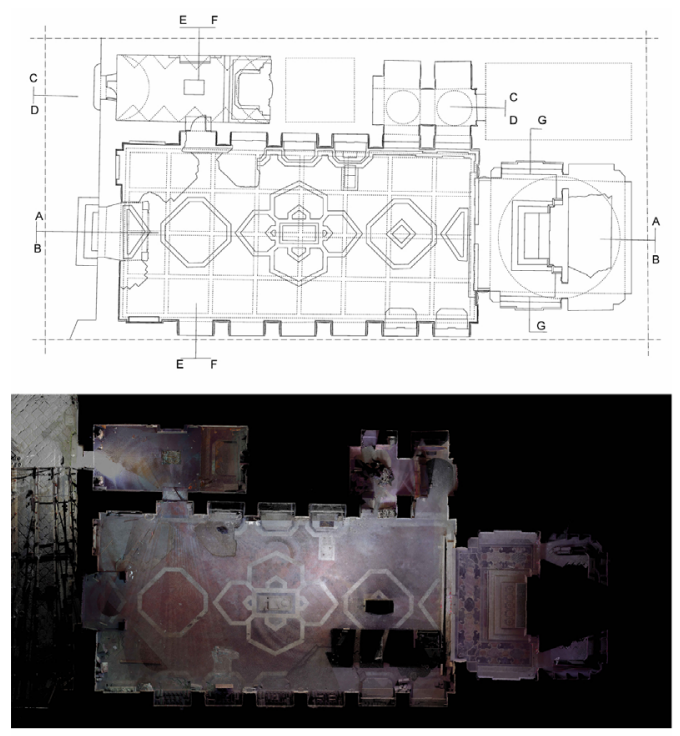
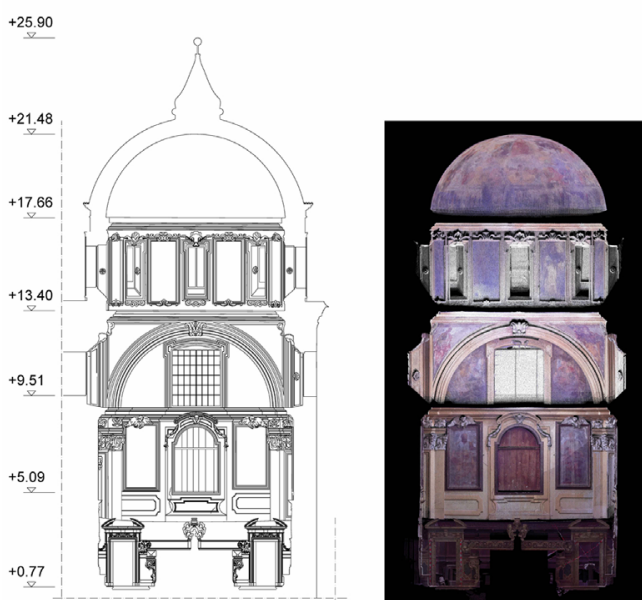
Fig. 12. Flusso metodologico dei dat: dal BIM al BIMH.

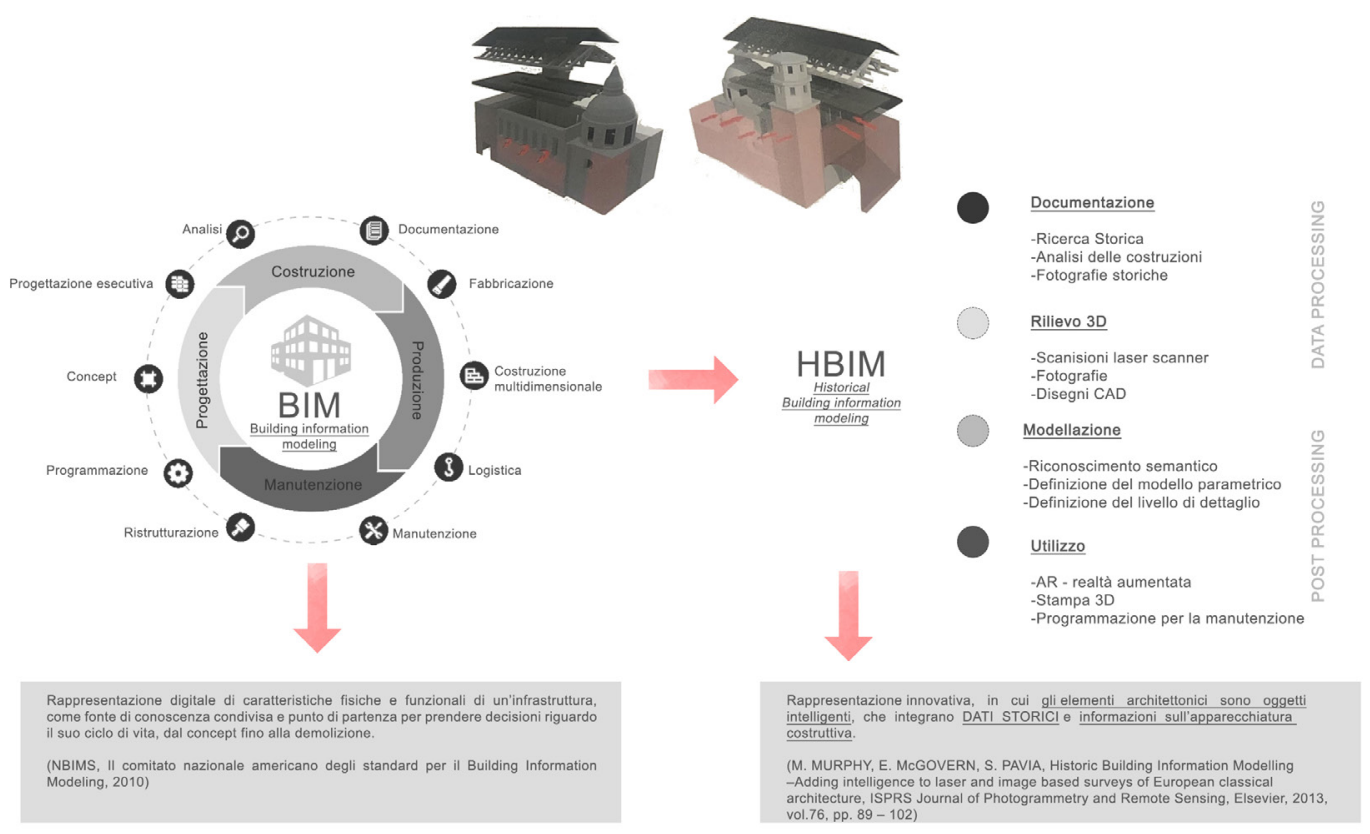

Note

[I] Le attività oggetto del presente contributo rientrano nel più ampio progetto di riqualificazione, restauro e rifunzionalizzazione del Complesso Monumentale di Santa Maria del Popolo degli Incurabili - Studi propedeutici alla progettazione: il quadro esigenziale e gli indirizzi metodologici che l'autrice ha condotto su incarico del Consorzio Universitario Benecon; Presidente Prof. Carmine Gambardella, Cattedra UNESCO on Landscape, Cultural Heritage and territorial Governance, Presidente del Consorzio Universitario Benecon.

[2] La regolarità della pianta della città di Napoli, desumibile dall'ortogonalità dei tracciati stradali, identificati in tre attraversamenti principali in senso est-ovest (plateiai o decumani) e in non meno di venti attraversamenti secondari in senso nord-sud (stenopoi o cardini) e dall'orientamento dei principali edifici, si interrompe in diverse arre; il fenomeno è indotto dall'esigenza di adattare lo schema urbano alla morfologia del terreno e di creare spazi adeguati a monumenti [De Simone 2019].

\section{Riferimenti bibliografici}

Balzani M., Raco F., Suppa M. (2019). Protocolli di acquisizione e gestione dati per la documentazione, rappresentazione e conservazione del patrimonio culturale danneggiato dal sisma. In Paesaggio Urbano, I, pp. |6|-169.

Cardaci A., Innocenti S. (2020). Dal faro per il mare al pozzo per il cielo: la chiesa di Santa Croce a Bergamo nella memoria di Santa Maria della Grotta a Messina. In Arena A. et al. (a cura di). Connettere. Un disegno per annodare e tessere. Atti del $42^{\circ}$ Convegno Internazionale dei Docenti delle Discipline della Rappresentazione/Connecting. Drawing for weaving relationships. Proceedings of the 42th International Conference of Representation Disciplines Teachers, pp. 1902-I923Milano: FrancoAngeli.

Cosenza E., Prota A. (2019). Risanamento statico conservativo. In Bruno A., Pulli G. (a cura di). Riqualificazione, Restauro e Rifunzionalizzazione del Complesso Monumentale di Santa Maria del Popolo degli Incurabili, Studi propedeutici alla progettazione: il quadro esigenziale e gli indirizzi metodologici. Napoli: Gianni Editore.

De Simone A. (2019). Lo studio archeologico dell'area. In Bruno A., Pulli G. (a cura di). Riqualificazione, Restauro e Rifunzionalizzazione del Complesso Monumentale di Santa Maria del Popolo degli Incurabili, Studi propedeutici alla progettazione: il quadro esigenziale e gli indirizzi metodologici, pp. 15- 18. Napoli: Gianni Editore.

Fatta F. (2020). Prefazione/Preface. In Arena A. et al. (a cura di). Connettere. Un disegno per annodare e tessere. Atti del $42^{\circ} \mathrm{Con}-$ vegno Internazionale dei Docenti delle Discipline della Rappresentazione/Connecting. Drawing for weaving relationships. Proceedings of the 42th International Conference of Representation Disciplines Teachers, pp. I3-24. Milano: FrancoAngeli.

Gambardella C. (2005). Sguardo e destino. In Gambardella C., Martusciello S. (a cura di). Le Vie dei Mercanti, Rappresentazione come governo della modificazione. Atti del II International Forum of Studies "Le Vie dei Mercanti", pp. I 5-2 I. Capri, 3-5 giugno 2004. Napoli: Edizioni Scientifiche Italiane.

Gambardella C. et al. (20 I7). II rilievo digitale integrato del Pio Monte della Misericordia a Napoli. In Abitare la Terra - Dwelling on Earth, XVI, n. 4I, pp. 48-57.

Papa L.M., D'Agostino P. (2020). Un processo integrato di conoscenza e visualizzazione. II castello della Reggia di Portici. In Arena A. et al. (a cura di). Connettere. Un disegno per annodare e tessere. Atti del $42^{\circ}$ Convegno Internazionale dei Docenti delle Discipline della Rappresentazione/Connecting. Drawing for weaving relationships. Proceedings of the 42 th International Conference of Representation Disciplines Teachers, pp. 25 I 5-2532. Milano: FrancoAngeli. 
Portoghesi P. (20 I 8). Editoriale. In Abitare La Terra, Quaderni vol. I, supplemento al numero 49, pp. 3, 4.

Salzano A. (2019). La redazione del progetto con la metodologia building information modeling (BIM). In Bruno A., Pulli G. (a cura di). Riqualificazione, Restauro e Rifunzionalizzazione del Complesso Monumentale di Santa Maria del Popolo degli Incurabili, Studi propedeutici alla progettazione: il quadro esigenziale e gli indirizzi metodologici, pp. 347, 348. Napoli: Gianni Editore.

Vitulli E. (2019). Indicazioni sulle opere d'arte presenti nel complesso degli Incurabili. In Bruno A., Pulli G. (a cura di). Riqualificazione, Restauro e Rifunzionalizzazione del Complesso Monumentale di Santa Maria del Popolo degli Incurabili, Studi propedeutici alla progettazione: il quadro esigenziale e gli indirizzi metodologici, p. I57. Napoli: Gianni Editore.

Zerlenga O. (2007). Dalla grafica allinfografica. Nuove frontiere della rappresentazione nel progetto di prodotto e di comunicazione. Foggia: Claudio Grenzi Editore.

Autore

Rosaria Parente, Consorzio Universitario Benecon, rosaria.parente@benecon.it

Per citare questo capitolo: Parente Rosaria (2021). Disegno di rilievo fondativo di una ricerca multidisciplinare presso il Complesso degli Incurabili/ Design of Originating Survey of a Multidisciplinary Research at the Complex of the Incurables. In Arena A., Arena M., Mediati D., Raffa P. (a cura di). Connettere. Un disegno per annodare e tessere. Linguaggi Distanze Tecnologie. Atti del $42^{\circ}$ Convegno Internazionale dei Docenti delle Discipline della Rappresentazione/Connecting. Drawing for weaving relationship. Languages Distances Technologies. Proceedings of the 42th International Conference of Representation Disciplines Teachers. Milano: FrancoAngeli, pp. 2549-2570. 


\title{
Design of Originating Survey of a Multidisciplinary Research at the Complex of the Incurables
}

\author{
Rosaria Parente
}

\section{Abstract}

The research on the Monumental Complex of Incurables, in the ancient center of Naples, is an experience of great interest due to the opportunity granted concerning the connection and interaction between disciplinary knowledge. The purpose was to optmize the hospital functions, the museum functions and the historical container itself. The survey and the complex representation of the monument were the essential condition for integrating the different disciplinary fields. The re-design, historicized at the date, allows to the drawer to retrace the generating form of the project, retracing the diachronic process from its creation to the modifications that have occurred over time. The Complex appears as a unitary in a contemporaneity of what does not have the same date. The knowledge and survey activity has retraced, in the becoming of the forms of the monument, the founding traces of the original project and subsequent projects, allowing to reveal the geometric matrices that give the shape of the physical model in relation to the consolidated protocols of the survey. From the project of discretization and measurement of built physicality inserted in the environmental context, also in relation to anthropic activities, the activity has set itself the goal of re-establishing a heritage of data to make transparent, through BIMH, the evolution of the monumental complex useful for the safeguarding, protection and maintenance of a pre-existing complex to guide the resilient project of the monumental 'factory'.

\section{Keywords}

technologies, survey, Incurables, 3D laser, BIMH.
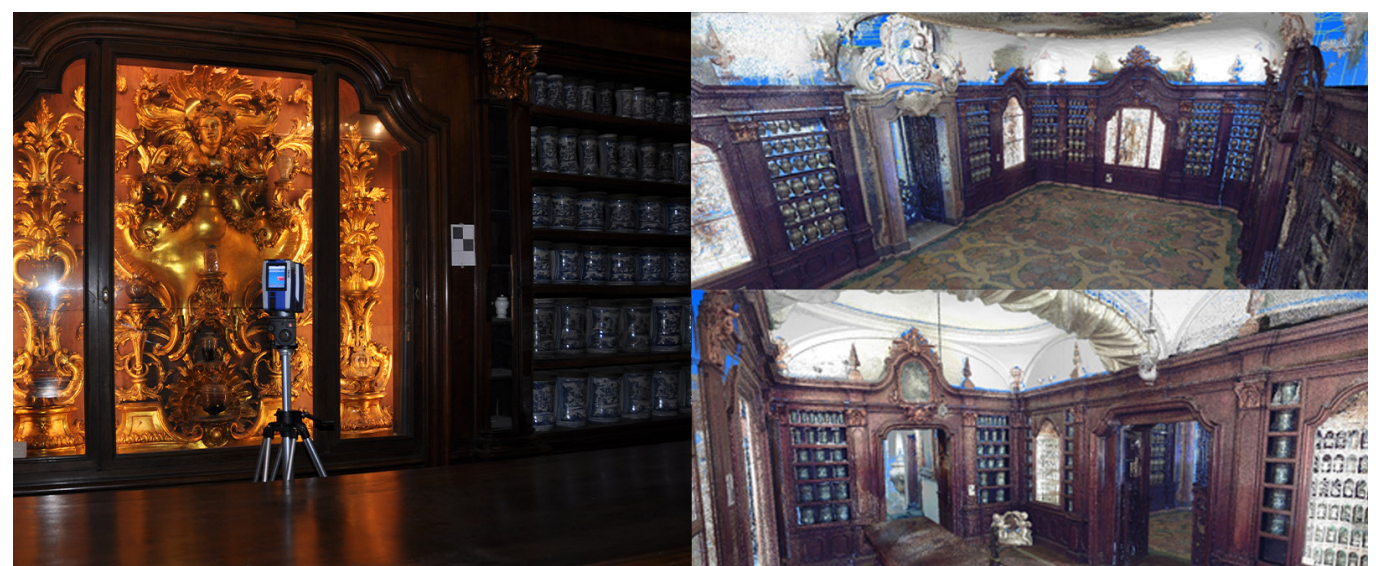


\section{Introduction}

The survey and knowledge activity, which I conducted on assignment by Benecon University Consortium, at the sixteenth-century hospital complex Santa Maria degli Incurabili, an imposing building whose architectural, functional and historical uniqueness made it one of the significant places on the UNESCO World Heritage Site of the ancient center of Naples, is part of an articulated and innovative strategic program, based on the participation of archaeological, legal, geological, geognostic, territorial planning, seismic, structural, technological, history of architecture, monumental restoration skills, and historical / artistic [I].

The restoration interventions were necessary, as well as for a poor maintenance of the structure, especially following several collapses that affected the vault supporting the floor of the church of Santa Maria del Popolo degli Incurabili inside the monumental complex. The connection, created between the different skills put in place, was of fundamental importance for the management of knowledge of an architectural asset so deeply stratified and contaminated. The knowledge involved concerned the archeology of the Caponapoli site, the architecture of the factory, the urban evolution up to the study of the historical and artistic heritage, of which the eighteenth-century Pharmacy certainly constitutes the most important and well-known part.

The Pharmacy is a work not only from an architectural point of view but also from an artistic and historical point of view since in it there are important wooden stalls in which an extraordinary collection of albarelli and idrie, particulare vases decorated in monochrome chiaroscuro with biblical and allegorical representations, made by Lorenzo Salandra. They represent a unicum that must be preserved in its entirety. These are small cylindrical vases with majolica whose representations are often repeated [Vitulli 2019].

Fig. I. Survey by the Benecon airborne

platform, view of the City of Naples and focus on the Historic Pharmacy of S. Maria del Popolo deg Incurabili.

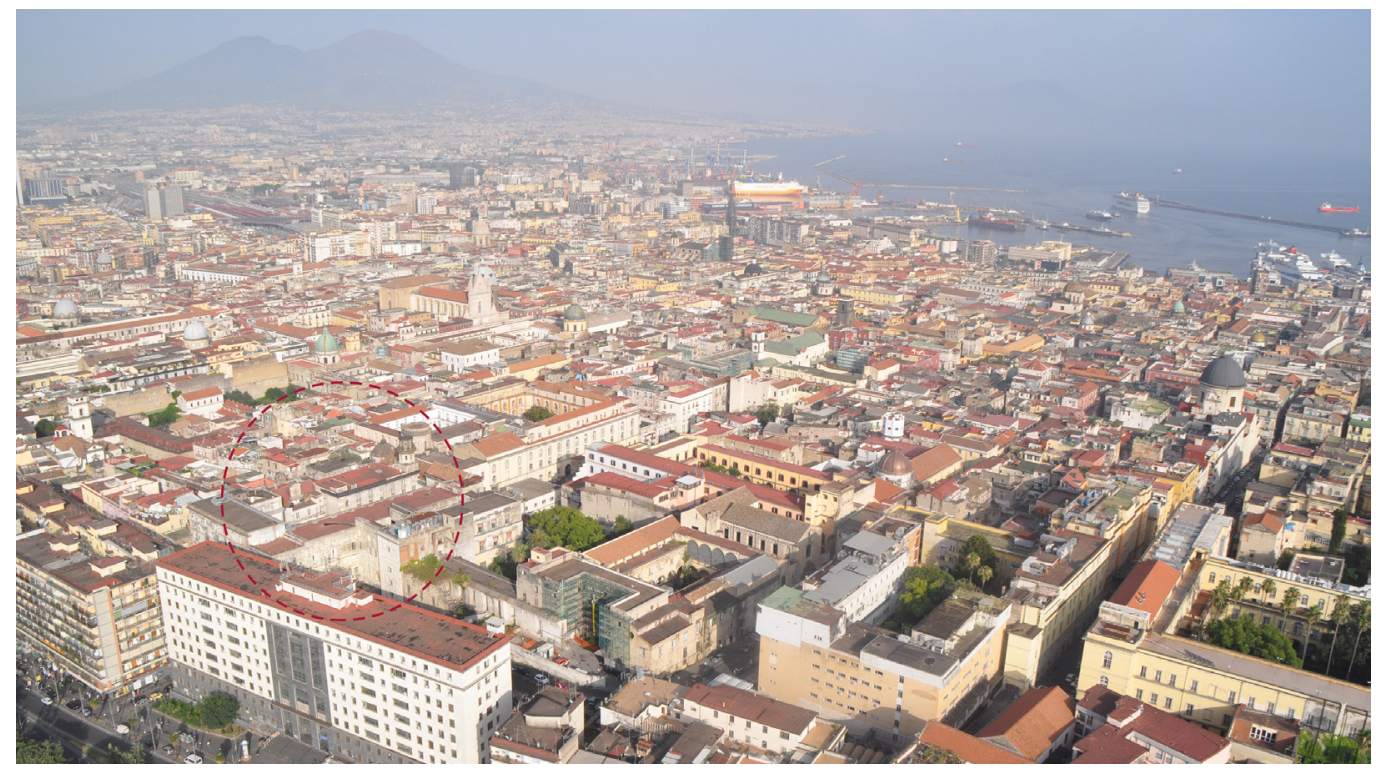

From the archaeological survey to the spatial and morphological characterization of the architectural artefact

The monumental complex is located in an archaeological area of great interest, Caponapoli, a hill of the government in the Greco-Roman era which later became a monastic citadel, characterized by ups and downs, between squares and ancient cloisters [I]. On the millenary stones of Caponapoli, between the Porta San Gennaro and that of Constantinople, there were bastions to guard the city but since the first half of the eighteenth-century 
Fig. 2 Focus on Pharmacy, airborne survey and photographic survey.

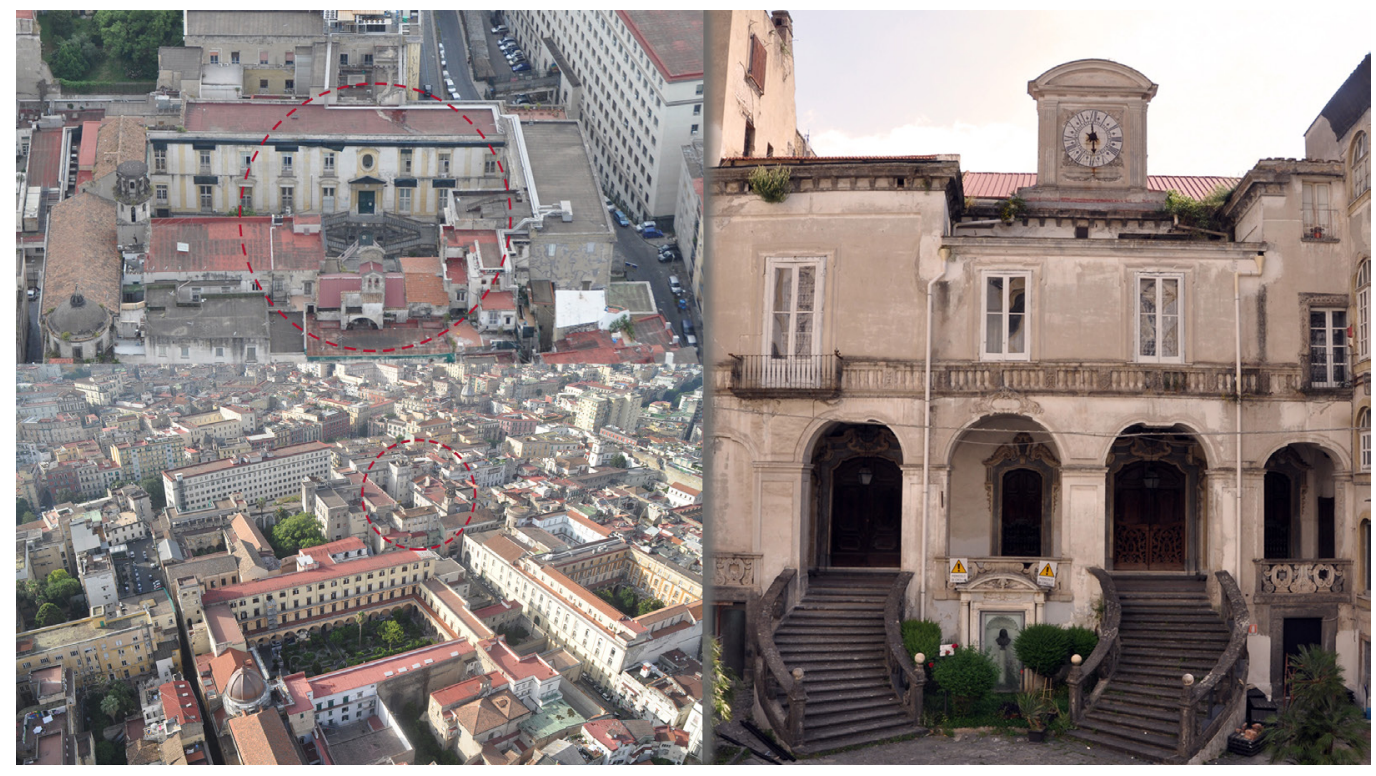

human care prevailed over military needs. The complex is the result of the union of two distinct organisms: the original one of the Incurables, the sum of various building interventions starting from 1521 and in the current configuration from the beginning of the $19^{\text {th }}$ century, and the Convent of Santa Maria delle Grazie in Caponapoli, whose foundation dates back to 1453, aggregated to the hospital in 1809.

In I52I, Francesca Maria Longo, after a miraculous recovery, began the work for the construction of the hospital by purchasing some houses in a healthy area of Sant' Aniello, the highest site of the Greek plant of Neapolis or the area which will take the name of Caponapoli and where the Church of Sant'Agnello Maggiore will rise in the Middle Ages.

The archaeological survey proved to be of fundamental importance for the definition of the diachronic stratification of the area and the accumulation of the integral of historical volumes. Vertical geo-archaeological surveys with continuous coring were carried out which revealed the presence of several wells aligned along the stenopoe [2] of via Armanni and the street of Consolazione. A northern section of the city walls and a reticulated work structure were also found.

The contamination of knowledge has found in the survey the main tool for the representation of the architectural artefact; in fact, all knowledge creates preparatory studies for planning. The geometric surveys, developed with the aid of digital technologies, have also allowed the definition of the current state of decay and structural instability, which is still under constant monitoring. The geological study of the site provided with the help of underground inspections, surveys and excavations for sub-terra knowledge characterized by volcanic soils on a tuff base and an ancient system of cavities and wells. The geotechnical analysis also conducted through investigations and instrumental checks has reconstructed, in the short time, the instability in the foundation and the natural and anthropogenic causes that determined them.

The digital model is configured as the digital 'place' in which to analytically archive all the scientific data produced ex ante, in fieri and ex post the restoration intervention, establishing itself as a multidimensional digital model of architecture, which can always be implemented and interrogated at multiple levels of in-depth analysis and according to multiple investigative directions [Pisacane 2017].

The phases of investigation and representation of the environments as illustrated in the figure 3, were an opportunity to make assessments on the role of the Surveyor who, investigating reality and representing it, engages in a production process capable of starting a chain of knowledge which, starting from the research of technologies, tools, means and surfaces, materials, colors, it creates the conditions to use a language of representation as a 
Fig. 3. The phases of investigation with laser scanner and planning for the representation of the surveyed places.

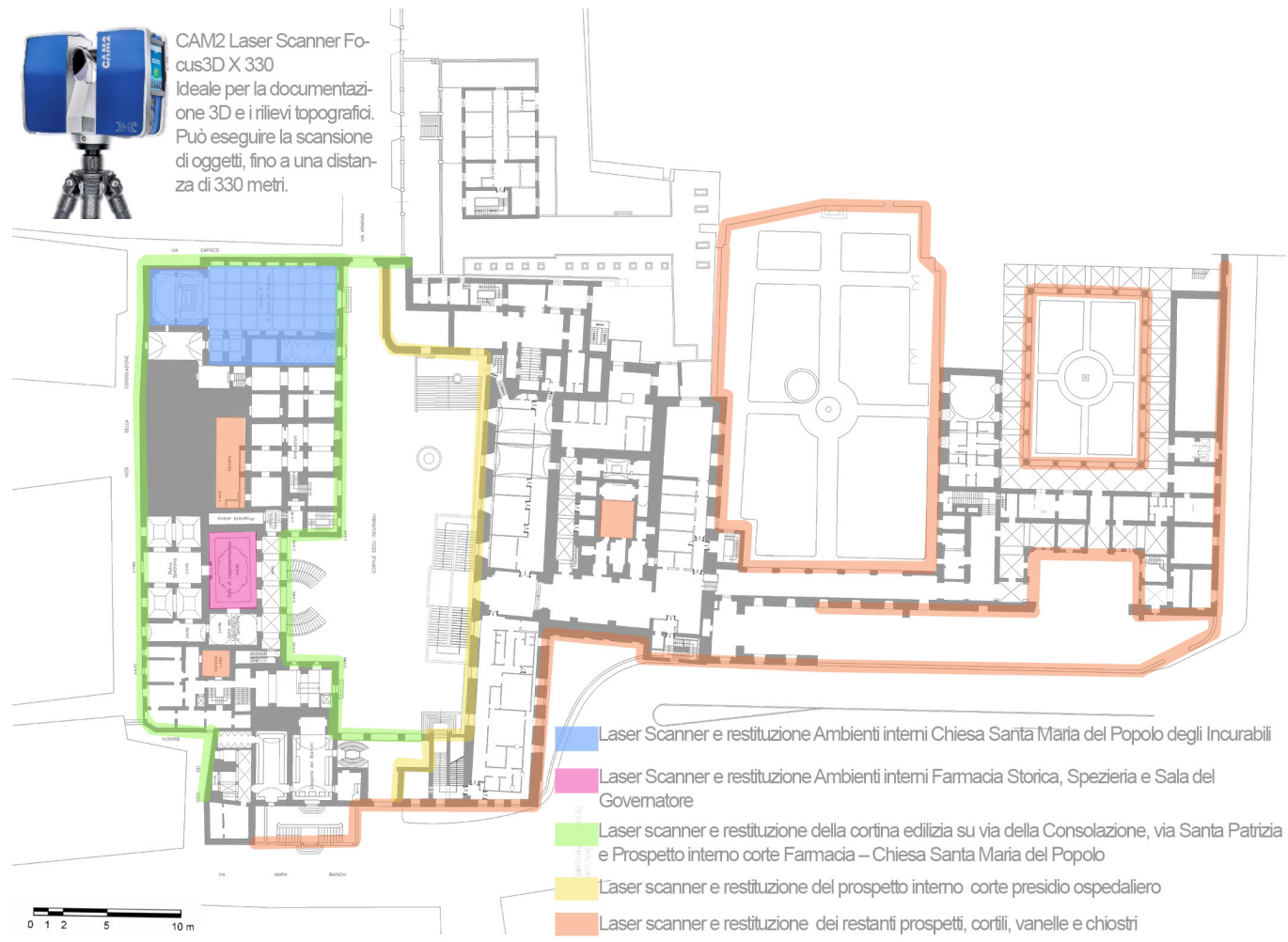

'toolbox' which it uses to trace, to make visible and transmissible the material culture, sources, thought, moods, emotions.

Measuring and capitalizing on the infinite reasons of nature, as Leonardo recommends, means recognizing the genetic heritage, the identity of the founding places of that continuous process of restoration and regeneration as a modification against any hypothesis of transformation: transforming implies an action dictated only by a technological necessity carried out by going beyond the limit imposed by knowledge [Gambardella 2005].

The first phase aimed at the geometric and morphological characterization of the architectural artefact consisted in the materialization and definition of the topographical framing network. This is a fundamental operation for the creation of a network to which to refer the numerous scans ( 125 scans, 23 GB of raw data, more than 2 million points acquired) with laser scanners that involved the internal environments of the historic Pharmacy, the Spezieria, the Governor's room and the Church of Santa Maria del Popolo as well as the elevations of the internal building curtains, the elevations of the external building curtains and the survey of the roofs of the entire complex.

To obtain an accurate plano-altimetric framing of the area in front of the pharmacy, a celerimetric survey was carried out with the Trimble VX total station integrated by topographic points acquired with the Trimble RIO GNSS receiver, in order to also obtain an accurate geographical positioning. The GNSS receiver has been configured in NRTK (Network Real Time Kinematic) mode thus exploiting the differential corrections of the Italpos network. This network, with national coverage, is made up of 24-hour operating GNSS receivers - called Permanent Stations- which continuously provide data for the topographical classification. The points of the aforementioned network can be defined as trigonometric vertices, being their coordinates and the entire network certified by the Italian Military Geographical Institute (IGMI); therefore, the points obtained, thanks to the technical characteristics of the Trimble RIO receiver supplied with the Benecon, were acquired with sub centimeter precision.

The topographical network therefore was carried out in the open spaces surrounding the Pharmacy, the church and the whole complex in order to define the relative shares and 
the spatial location of the internal and external underground services, a possible cause of deterioration of the architectural and decorative systems.

The study, however, provided for an initial cognitive phase of the area affected by the restoration intervention in a GIS environment, it was possible to compare the quoted plan created with the VX total station owned by the Benecon University Consortium and the shares from DTM of the Campania Region. From this comparison it was possible to evaluate any changes in altitude between the points detected in the acquisition campaign in April 2019 and the points deducted from the DTM of the Campania Region dated 20II.

The need to integrate information related to a univocal information base, if linked to the knowledge of objects that are located in larger complex systems, manifests the need to produce graphic information through a process of representation and visualization, both on a territorial or urban scale. as for the detail one [Papa, D'Agostino 2020].

Given the high degree of interactions between the different disciplines present in the project, it is necessary to ensure a high level of integration between models and documents for proper conduct of the design levels. According to the principle of the BIM methodology of "Being with the end in mind", the information models produced must be used in the creation and management phase of the Facility management [Salzano 20।9].

Fig. 4. The threedimensional survey of the internal place and acquisition of topographic points by the Trimble RI GNSS receiver in the courtyard in front of the Pharmacy.

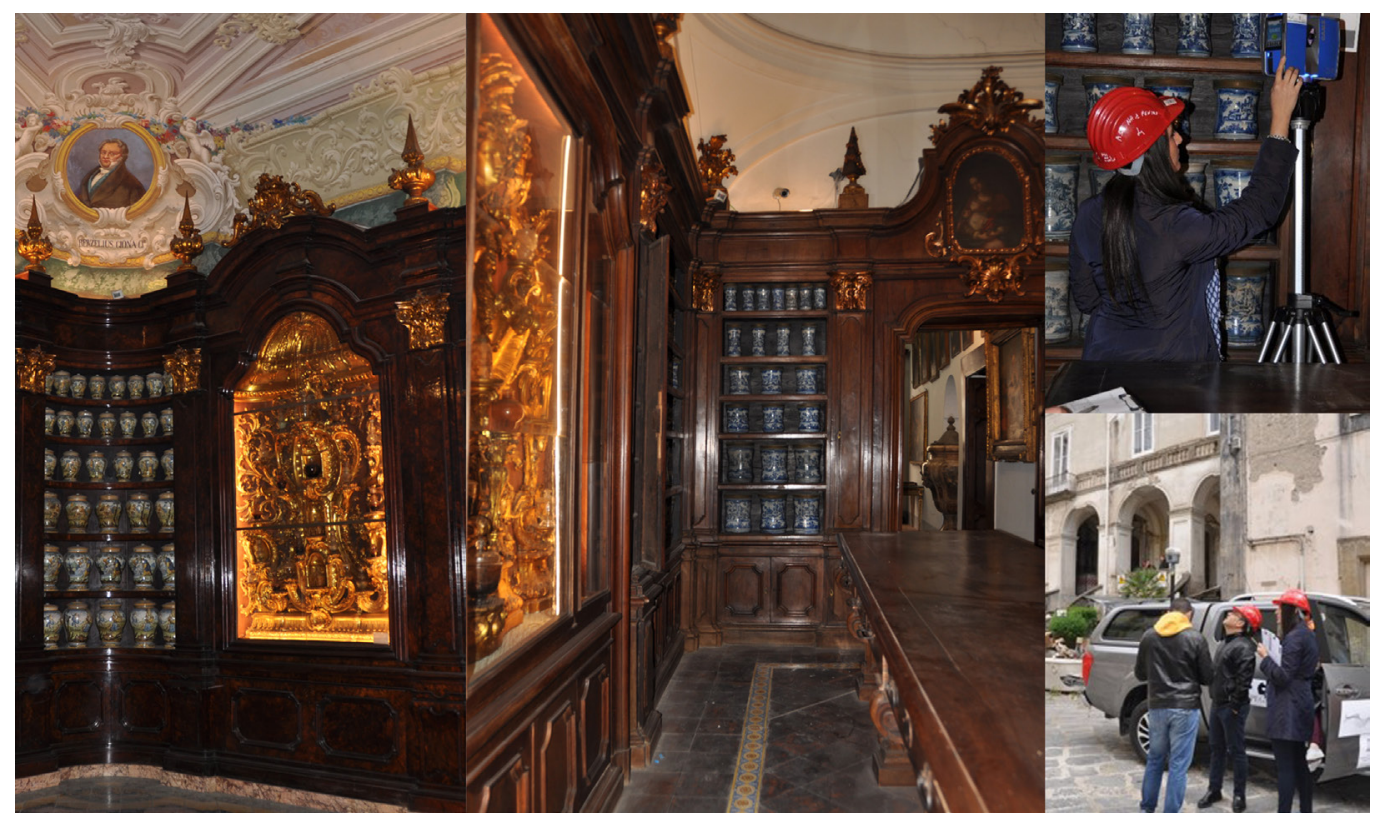

\section{Survey by laser scanner}

The research activity aimed at restoring the work, has intended to provide, through the 3D survey, that contribution in terms of historical, geometric, constructive and stratigraphic knowledge, which appears substantial for the operations of conservation, cataloging and enhancement of the architectural asset.

The Complex of the Incurables presents itself in a conformation that is the result of different evolutionary processes that over time have led it to be a real building aggregate composed of different structural units, built in different eras and with a different degree of connection between them. for the purposes of the evaluation of seismic safety, the identification of original units, the process of evolution of the structure and the identification of the local construction technique are indispensable. For this particular type of structures, the knowledge phase through the use of laser scanner technologies allows not only to identify the elements that make up the structure but also to define the interactions between the different units that make up the aggregate [Cosenza, Prota 2019]. 
Fig. 5. Cloud cleaning and filtering, mapping with image data.

Fig. 6. Example of orthophoto, elaborated on the internal view of the Pharmacy, which does not require scale corrections.
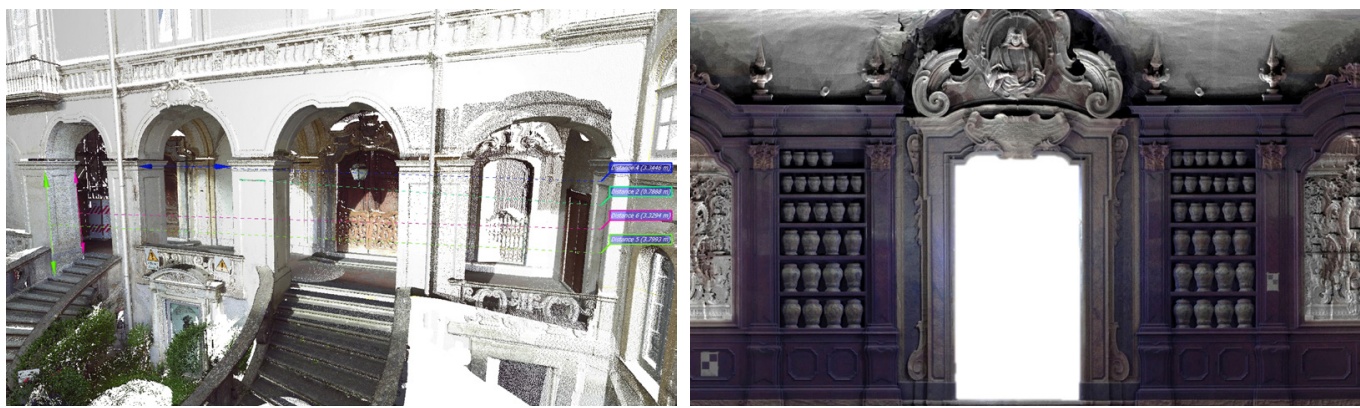

The seismic safety assessment found the probable cause of the collapses that occurred in the area in the malfunctioning of water disposal.

The survey operations were carried out by integrating the use of multiple land and airborne instruments. The technology used to return the point cloud is the FARO Focus 3D X330, a phase difference 3D laser scanner [3].

As is known, automatic survey is characterized by a sort of inability of the measuring instrument to make 'intelligent' choices [Cardaci, Innocenti 2020].

The scanning activity can in fact take a long time and return a very large and complex data set so it is of fundamental importance to plan the scan plans in advance by focusing and having a clear idea of the goal to be achieved. The laser detects all the elements it encounters in the surveyed scene, so it is necessary to clean and filter the point clouds. Once these cleaning and filtering phases were completed, the cloud, resulting from the mosaic of the I 25 clouds detected, was mapped with the image data to allow a more precise identification of the textures and characteristics of the structure [4].

If on the one hand, the scanning laser detects everything that is around itself and is visible, without actually seeing what he measures and without distinguishing the parts of the building by importance, it is also true that this allows us to extract measurable orthophotos which represent a precious source of the state of the places to date since no detail can escape this kind of survey so, where each element could be interpreted simply as a sequence of points spaced apart by technology, it is there that the primacy of the mind intervenes that is, the founding primacy of 'drawing in our mind' can be reaffirmed. Ultimately, an automatic acquisition tool does not possess the human capacity to interpret shapes and geometries

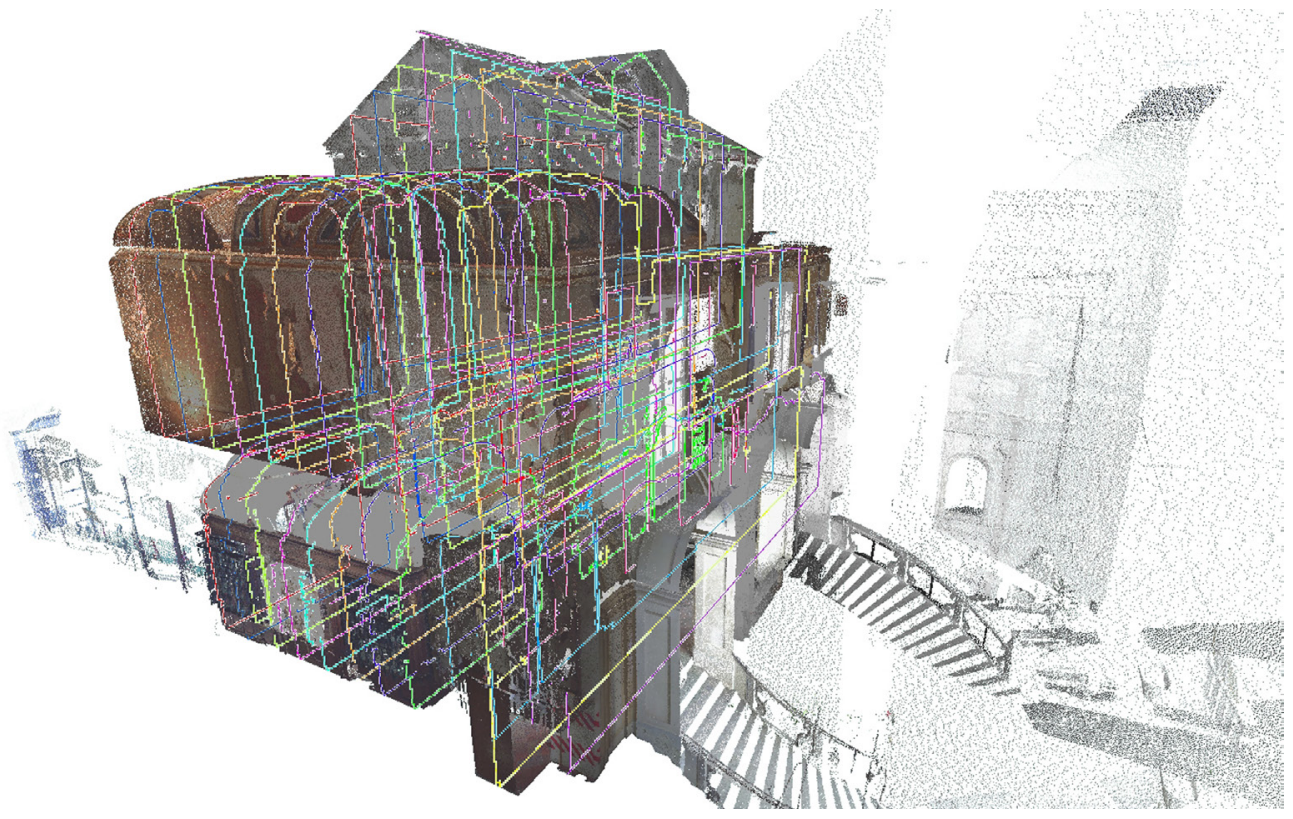



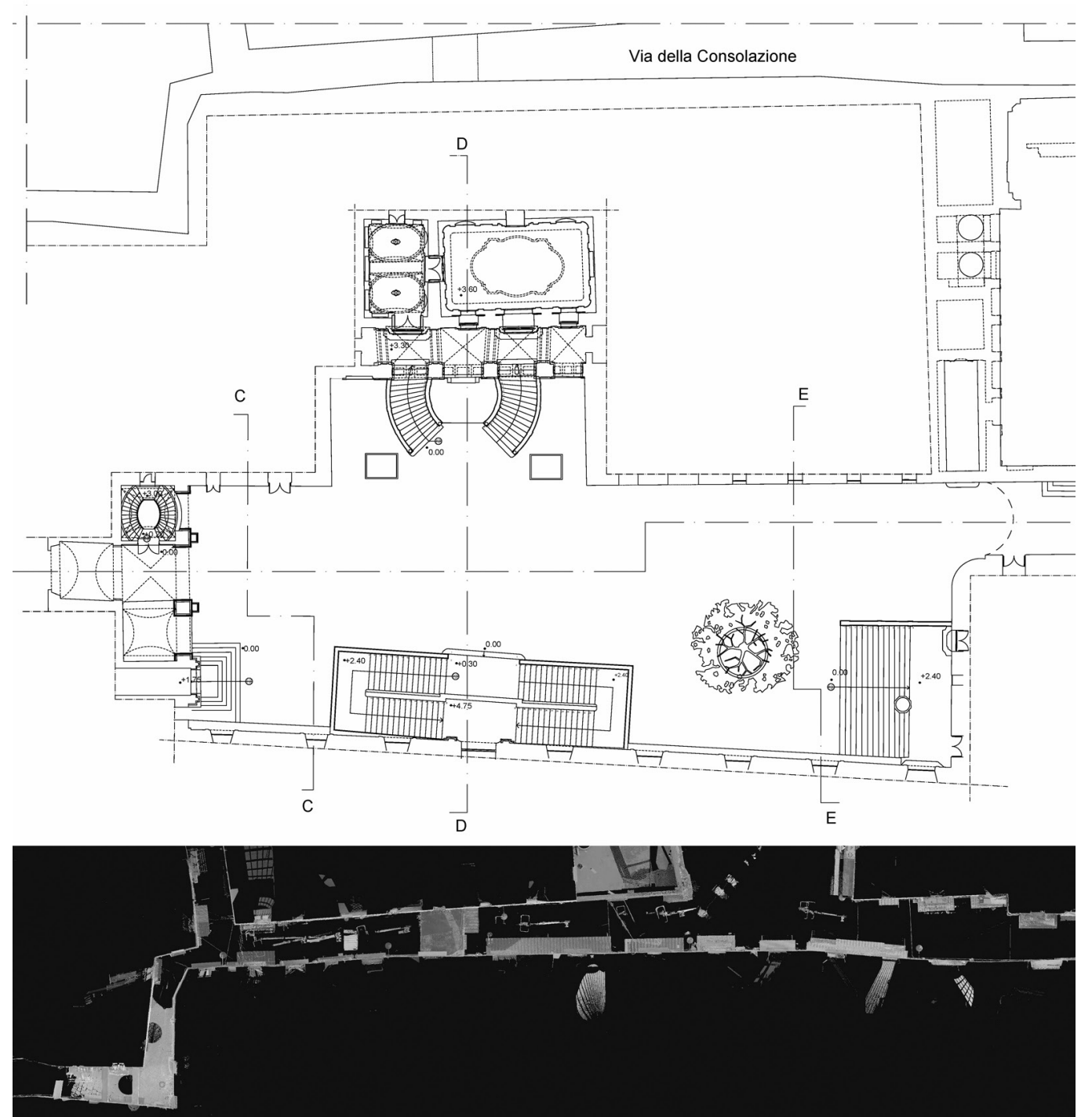

Planimetria corte interna Farmacia +6.50 
and is therefore capable of returning orthographic and / or cross-sectional projections, such as simple sequences of points, not conditioned by a perhaps erroneous and previous interpretation of the spatiality of the monument.

But the possibility of transparently superimposing the survey of the exterior and interior has led to consider and verify, in the case study in question, some functional interpretations of the building, it has been possible to extrapolate rectified views of the whole that have shown in real time the cracking state of the walls, subsidence and hollows in the floors as in the emblematic case of the room above the Pharmacy room, or of the topographical trend of street of Consolazione, overlooking the building most affected by the collapse.

It is almost certain that some small details would not have been highlighted by a traditional survey since, only at the time of generation in the dedicated software it was possible to choose both the section plane but also the depth range and therefore visibility of the same in order to obtain as many slicing as considered fundamental for the characterization and design of the most complex geometries [5].

Considering the theme of technology discussed here, Ornella Zerlenga's opinions about technological innovation that strengthens the ways of doing things and, in some respects, also introduces new forms of doing, are current, but the construction of project remains governed by the cultural and ethical sensitivity of those who intuit it, develop it, implement it, at least for now, where a substantial distinction still exists between man and computer, which marks the difference between the two: the organic dimension, for the former, and inorganic, for the second, and therefore, the possibility for the first to be intelligent, free to choose.
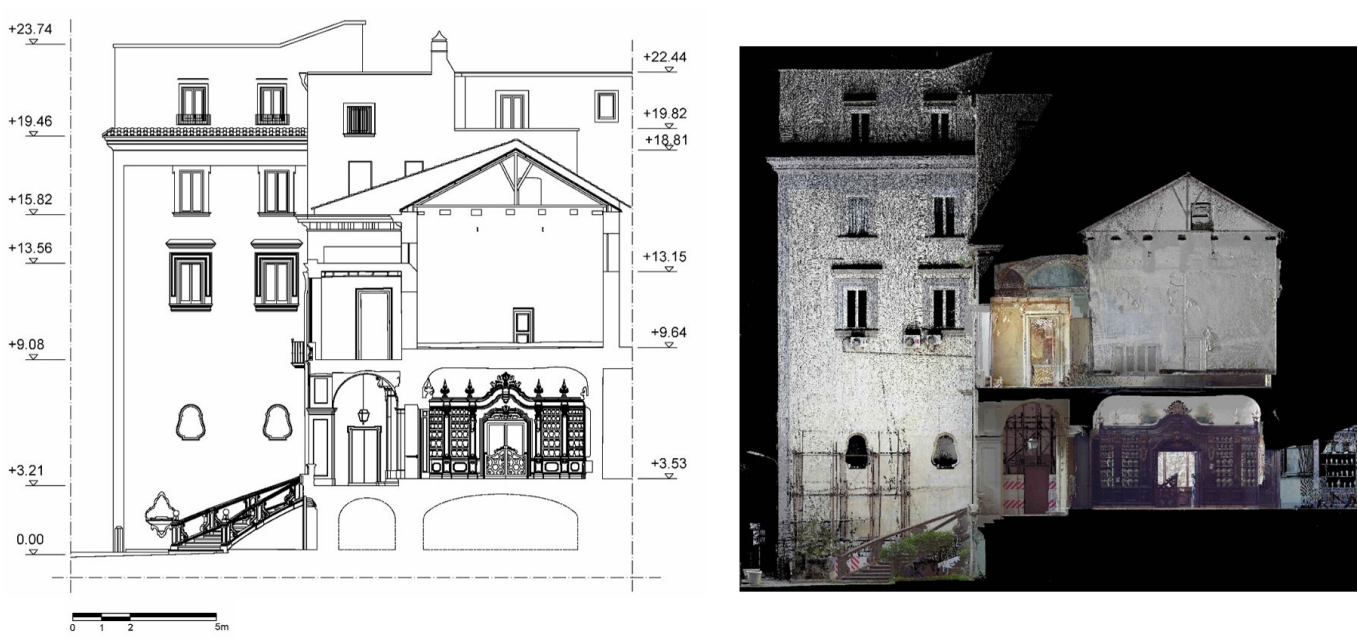

\section{Conclusions}

The connection and contamination between the most different disciplines and different knowledge, in the Research object of these notes, have allowed to Drawing to reaffirm its role as a 'synthesis' between the human and social sciences and the sciences of engineering and information technology. It is not just a matter of detecting, but of 'interpreting' and drawing inferences in order to then be able to intervene in the context of a plural thought, based on the multidimensionality of knowledge [Fatta 2020].

The restitution of a cognitive state, so thorough and exhaustive of the site and the factory of the Incurables, has allowed the same experts to define the methodological guidelines for the redevelopment on an urban scale, the static conservative rehabilitation and the architectural and artistic restoration. The restoration of the hospital of the Incurables will be implemented through the reuse of the same, partly as a museum structure and partly as a socio-health structure with territorial value. The treasures of the past must be digested and 
Fig. I0. A destra il prospetto dell'ingresso principale su via Maria Longo; a sinistra il prospetto nord su via Capozzi.
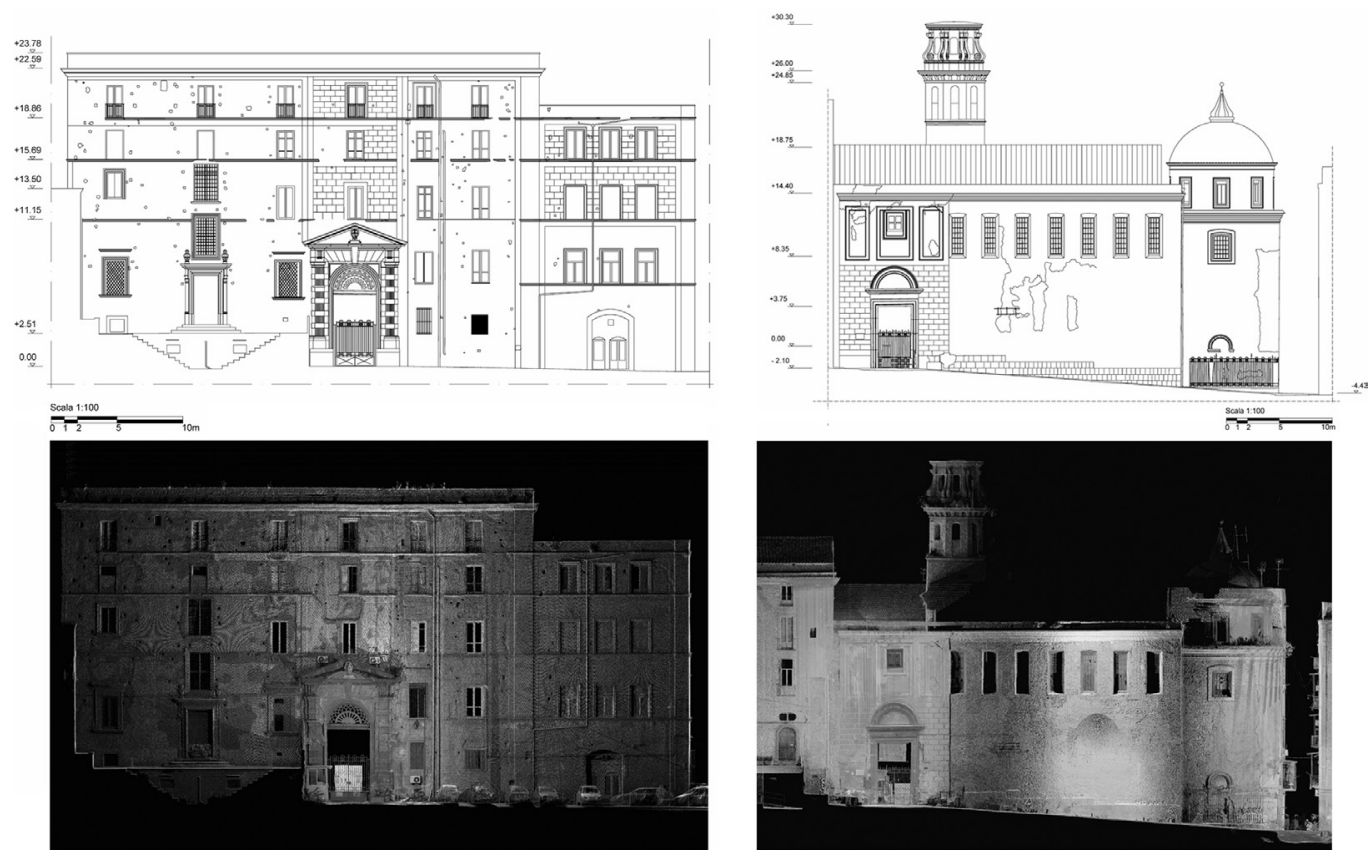

assimilated to be recreated or to feed the mission that each generation must face in order to give the heritage a new perspective.

The legacy demands interpretation but also the ability to re-create, to use the talents received by putting them to good use, to look at the past with new eyes, not only to listen to it, but also to freely decide in which direction to continue the route [Portoghesi 20I8].

With this in mind, the disciplinary sector of Drawing has proven, with its wide range of technologies and its ability to trace the minimum sign and the relationship between the parts, as the most effective medium for representing the legacy left to us since I500, by the founder of the Hospital of the Incurables, Maria Longo.

The case study is paradigmatic for the many monumental hospitals present throughout Italy, which have an important function for the territory and could find in the projects of the Recovery Fund the way to be restored and safeguarded.
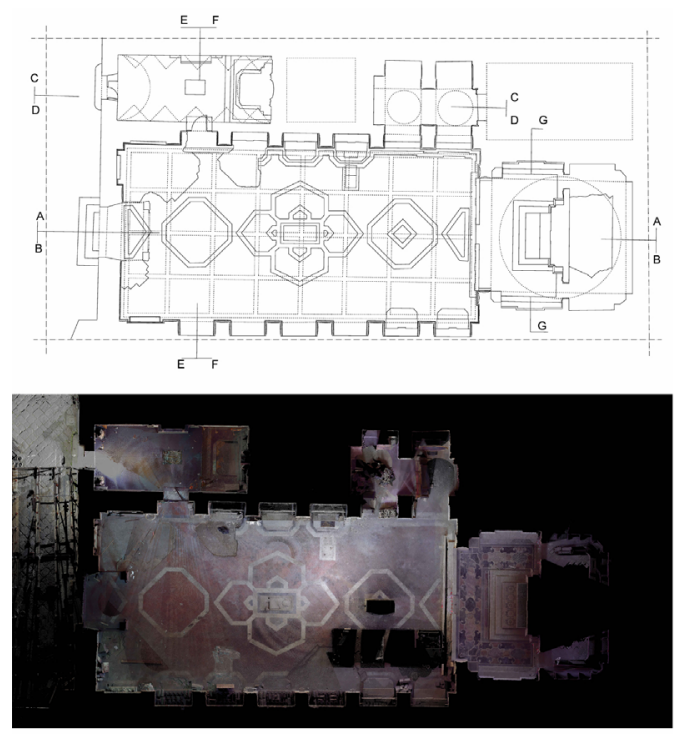
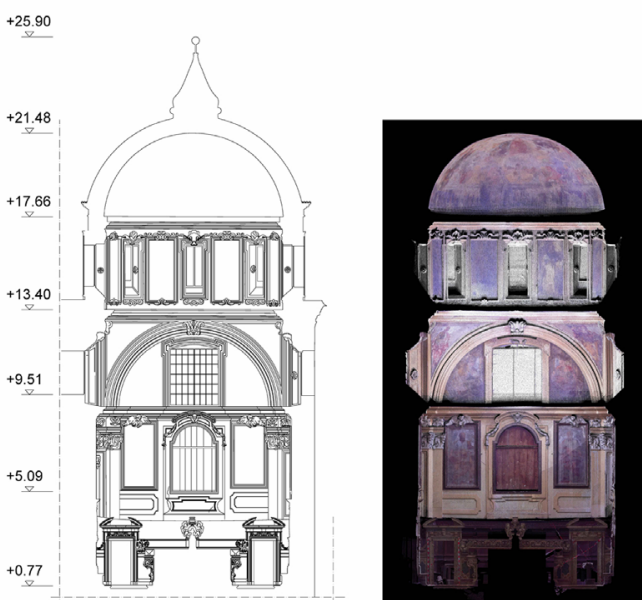
Fig. 12. Methodological flow-chart of data: from $\mathrm{BIM}$ to BIMH.

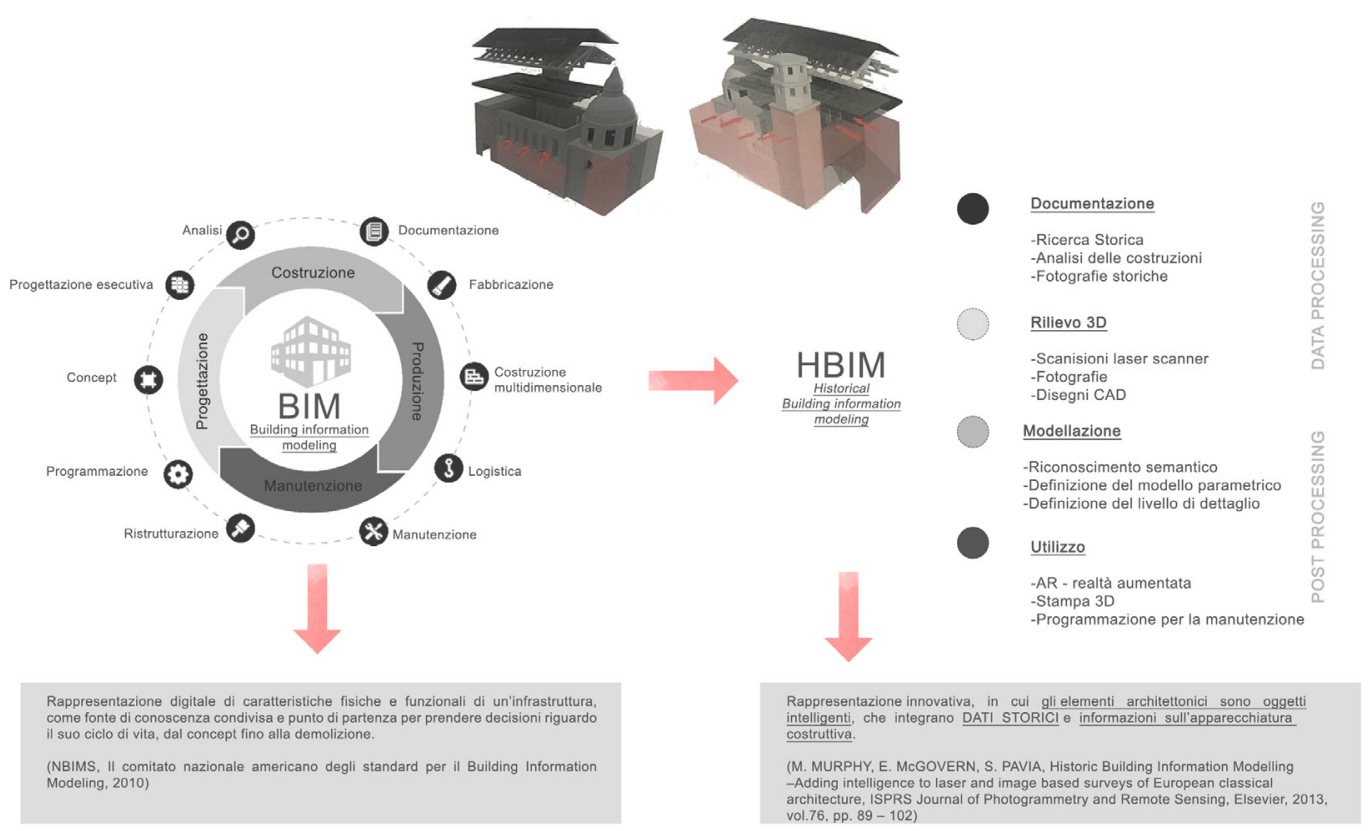

\section{Notes}

[I] The activities described in this text are part of the project of redevelopment, restoration and re-functionalization of the Monumental Complex of Santa Maria del Popolo degli Incurabili - Preliminary studies for the design: the requirements framework and the methodological guidelines that the author conducted on assignment by the Benecon University Consortium; President Prof. Carmine Gambardella, UNESCO Chair on Landscape, Cultural Heritage and Territorial Governance, President of the Benecon University Consortium.

[2] The regularity of the map of the city of Naples, deducible from the orthogonality of the road layouts, identified in three main crossings in the east-west direction (plateiai or decumani) and in no less than twenty secondary crossings in the northsouth direction (stenopoi or hinges) and from the orientation of the main buildings, it is interrupted in different areas; the phenomenon is induced by the need to adapt the urban layout to the morphology of the land and to create suitable spaces for monuments [De Simone 2019]

\section{References}

Balzani M., Raco F., Suppa M. (2019). Protocolli di acquisizione e gestione dati per la documentazione, rappresentazione e conservazione del patrimonio culturale danneggiato dal sisma. In Paesaggio Urbano, I, pp. |6|-169.

Cardaci A., Innocenti S. (2020). Dal faro per il mare al pozzo per il cielo: la chiesa di Santa Croce a Bergamo nella memoria di Santa Maria della Grotta a Messina. In Arena A. et al. (a cura di). Connettere. Un disegno per annodare e tessere. Atti del $42^{\circ}$ Convegno Internazionale dei Docenti delle Discipline della Rappresentazione/Connecting. Drawing for weaving relationships. Proceedings of the 42th International Conference of Representation Disciplines Teachers, pp. 1902-I923Milano: FrancoAngeli.

Cosenza E., Prota A. (2019). Risanamento statico conservativo. In Bruno A., Pulli G. (a cura di). Riqualificazione, Restauro e Rifunzionalizzazione del Complesso Monumentale di Santa Maria del Popolo degli Incurabili, Studi propedeutici alla progettazione: il quadro esigenziale e gli indirizzi metodologici. Napoli: Gianni Editore.

De Simone A. (2019). Lo studio archeologico dell'area. In Bruno A., Pulli G. (a cura di). Riqualificazione, Restauro e Rifunzionalizzazione del Complesso Monumentale di Santa Maria del Popolo degli Incurabili, Studi propedeutici alla progettazione: il quadro esigenziale e gli indirizzi metodologici, pp. I5- 8. Napoli: Gianni Editore.

Fatta F. (2020). Prefazione/Preface. In Arena A. et al. (a cura di). Connettere. Un disegno per annodare e tessere. Atti del $42^{\circ}$ Convegno Internazionale dei Docenti delle Discipline della Rappresentazione/Connecting. Drawing for weaving relationships. Proceedings of the 42th International Conference of Representation Disciplines Teachers, pp. I3-24. Milano: FrancoAngeli.

Gambardella C. (2005). Sguardo e destino. In Gambardella C., Martusciello S. (a cura di). Le Vie dei Mercanti, Rappresentazione come governo della modificazione. Atti del II International Forum of Studies "Le Vie dei Mercanti", pp. I 5-2 I. Capri, 3-5 giugno 2004 Napoli: Edizioni Scientifiche Italiane.

Gambardella C. et al. (2017). II rilievo digitale integrato del Pio Monte della Misericordia a Napoli. In Abitare la Terra - Dwelling on Earth, XVI, n. 4I, pp. 48-57.

Papa L.M., D'Agostino P. (2020). Un processo integrato di conoscenza e visualizzazione. II castello della Reggia di Portici. In Arena A. et al. (a cura di). Connettere. Un disegno per annodare e tessere. Atti del $42^{\circ}$ Convegno Internazionale dei Docenti delle Discipline della Rappresentazione/Connecting. Drawing for weaving relationships. Proceedings of the 42th International Conference of Representation Disciplines Teachers, pp. 25 15-2532. Milano: FrancoAngeli. 
Portoghesi P. (20 I 8). Editoriale. In Abitare La Terra, Quaderni vol. I, supplemento al numero 49, pp. 3, 4.

Salzano A. (2019). La redazione del progetto con la metodologia building information modeling (BIM). In Bruno A., Pulli G. (a cura di). Riqualificazione, Restauro e Rifunzionalizzazione del Complesso Monumentale di Santa Maria del Popolo degli Incurabili, Studi propedeutici alla progettazione: il quadro esigenziale e gli indirizzi metodologici, pp. 347, 348. Napoli: Gianni Editore.

Vitulli E. (2019). Indicazioni sulle opere d'arte presenti nel complesso degli Incurabili. In Bruno A., Pulli G. (a cura di). Riqualificazione, Restauro e Rifunzionalizzazione del Complesso Monumentale di Santa Maria del Popolo degli Incurabili, Studi propedeutici alla progettazione: il quadro esigenziale e gli indirizzi metodologici, p. I57. Napoli: Gianni Editore.

Zerlenga O. (2007). Dalla grafica allinfografica. Nuove frontiere della rappresentazione nel progetto di prodotto e di comunicazione. Foggia: Claudio Grenzi Editore.

Author

Rosaria Parente, Consorzio Universitario Benecon, rosaria.parente@benecon.it

To cite this chapter. Parente Rosaria (2021). Disegno di rilievo fondativo di una ricerca multidisciplinare presso il Complesso degli Incurabili/Design of Originating Survey of a Multidisciplinary Research at the Complex of the Incurables. In Arena A., Arena M., Mediati D., Raffa P. (a cura di). Connettere. Un disegno per annodare e tessere. Linguaggi Distanze Tecnologie. Atti del $42^{\circ}$ Convegno Internazionale dei Docenti delle Discipline della Rappresentazione/Connecting. Drawing for weaving relationship. Languages Distances Technologies. Proceedings of the 42th International Conference of Representation Disciplines Teachers. Milano: FrancoAngeli, pp. 2549-2570. 